University of Rhode Island

DigitalCommons@URI

Open Access Dissertations

1964

\title{
The Potential of Chemicals and Pythium Species to Control Marasmius Fairy Ring
}

Peter Bent Adams

University of Rhode Island

Follow this and additional works at: https://digitalcommons.uri.edu/oa_diss

\section{Recommended Citation}

Adams, Peter Bent, "The Potential of Chemicals and Pythium Species to Control Marasmius Fairy Ring" (1964). Open Access Dissertations. Paper 434.

https://digitalcommons.uri.edu/oa_diss/434

This Dissertation is brought to you for free and open access by DigitalCommons@URI. It has been accepted for inclusion in Open Access Dissertations by an authorized administrator of DigitalCommons@URI. For more information, please contact digitalcommons-group@uri.edu. 


\section{THE POTENTIAI OF CHEMICALS AND PYTHIOM SPECIES}

TO CONTROL MARASMIUS FAIRY RING

$$
\text { by }
$$

Peter Bent Adams

A THESIS SUBMITTED IN PARTIAL FULFILLMENT OF THE REQUIREMENTS FOR THE DEGREE OF

DOCTOR OF PHILOSOPHY

IN

BIOLOGICAL SCIENCES

UNIVERSITY OF RHODE ISLAND

1964 


\section{DOCTOR OF PHILOSOPHY THESIS}

OF

PETER BENT ADAMS

Approved:

Thesis Committee:

Chairman

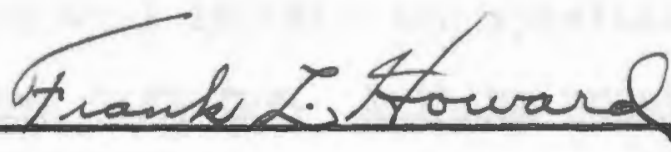

Thieton talomon

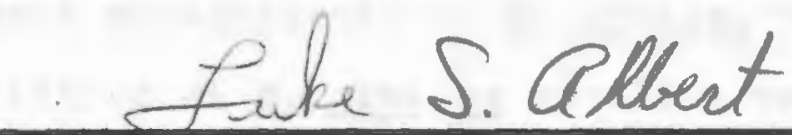

Dean of the Graduate School

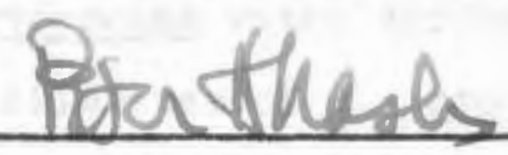




\section{ABSTRACT}

Fairy rings caused by Marasmius oreades Fr. and other fungl cause considerable damage to turfgrasses. The recommended control measures for this disease are either soll fumigation or digging up the affected turf and replacing it with noninfested soll. Both methods require subsequent reseeding or resodding of the area. Regults of two years' experimentation indicate that chemical control of falry ring disease is not practical at the present. Hence, the possibilities of blological control were explored.

This investigation has shown that Pythium artotrogus and other Pythium species will inhibit the mycelial growth of . oreades and Agaricus bisporus. Pythium artotrogus was more antagonistic to A. bisporus than was other Pythium species tested. Pythium ultimum and an isolate of $\underline{P}$. irregulare were more antagonistic to $\underline{M}$. oreades than was $\underline{P}$. artotrogus. Inhibition of $\underline{M}$. oreades mycelium was shown to

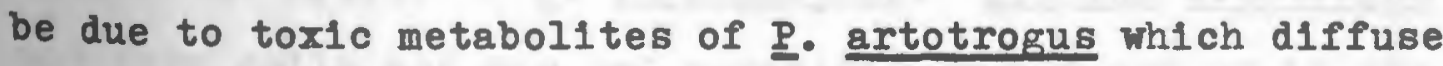
through an agar gel. Fresh culture filtrates of $\underline{p}$. artotrogus completely inhibited the growth of the agaric hyphal tips within twenty minutes. The biological activity of the f1ltrate was not reduced when kept at $7^{\circ} \mathrm{C}$ for prolonged periods, but it was shown to be thermolabile.

Studies on the effect of temperature on mycelial growth

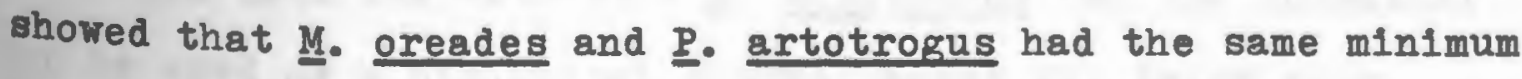
temperature requirement. The optimum temperature for growth 
was about $27^{\circ} \mathrm{C}$ for both fung1. Growth of P. artotrogus occurred at higher temperatures than M. oreades. At all temperatures $\underline{P}$. artotrogus had a growth rate of two to ten times that of M. oreades.

Maragmius oreades grew over a pH range of about 3.0 to 7.5 with an optimum of about 5.5. Growth of $\underline{P}$. artotrogus occurred from $\mathrm{pH} 2.5$ to above 7.7 with an optimum at 5.5 .

Pythium artotrogus was not parasitic to $A$. bisporus or M. ereades. However, this Pythium species was shown to parasitize the hyphae of $\underline{P}$. aphanidermatum, $\underline{P}$. debaryanum, $\underline{P}$. irregulare, P. splendens and P. ultimum. When encountering susceptible hyphae, the hyphal tip of $\underline{P}$. artotrogus colled around the host hypha followed by the formation of an appressorlum on the hyphal surface of the host. Following penetration, the infection hypha grew lengthwise in that of the host, degenerating the cellular contents as it advanced. Although

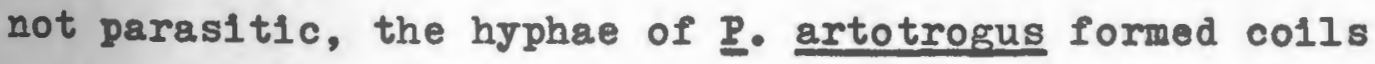
around the hyphae of P. arrhenomanes. Pythium artotrogus did not form coils and was not parasitic in its own or in the hyphae of P. graminicolum.

Of the many Pythium species that were shown to be antagonlstic to $A$. bisporus and $M$. oreades, only $\underline{\underline{P}}$. artotrogus was ohown to cause no injury to four species of Agrostis in laboratory pathogenicity tests.

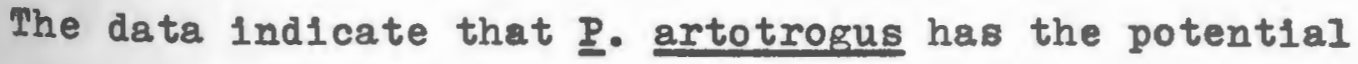
to be used as a biological control agent for fairy ring caused by $\mu$ oreades. However, since it was shown that 
P. artotrogus would not grow among the mycelial mass of elther A. bisporus or M. oreades, the antagonistic Pythium specles w1ll have to be applied to the turf on the outer edge and in advance of the fairy ring if it is to be a successful biological control agent. 


\section{ACKNOWLEDGEMENTS}

The author wishes to express his sincere appreclation to Dr. Frank I. Howard for serving as major professor and for his constructive criticism throughout the course of this investigation. Gratitude is also expressed to Dr. Iuke S. Albert and Dr. Milton Salomon for serving as committee members, and to Dr. Theodore $W$. Kerr for his critical review of this manuscript. 


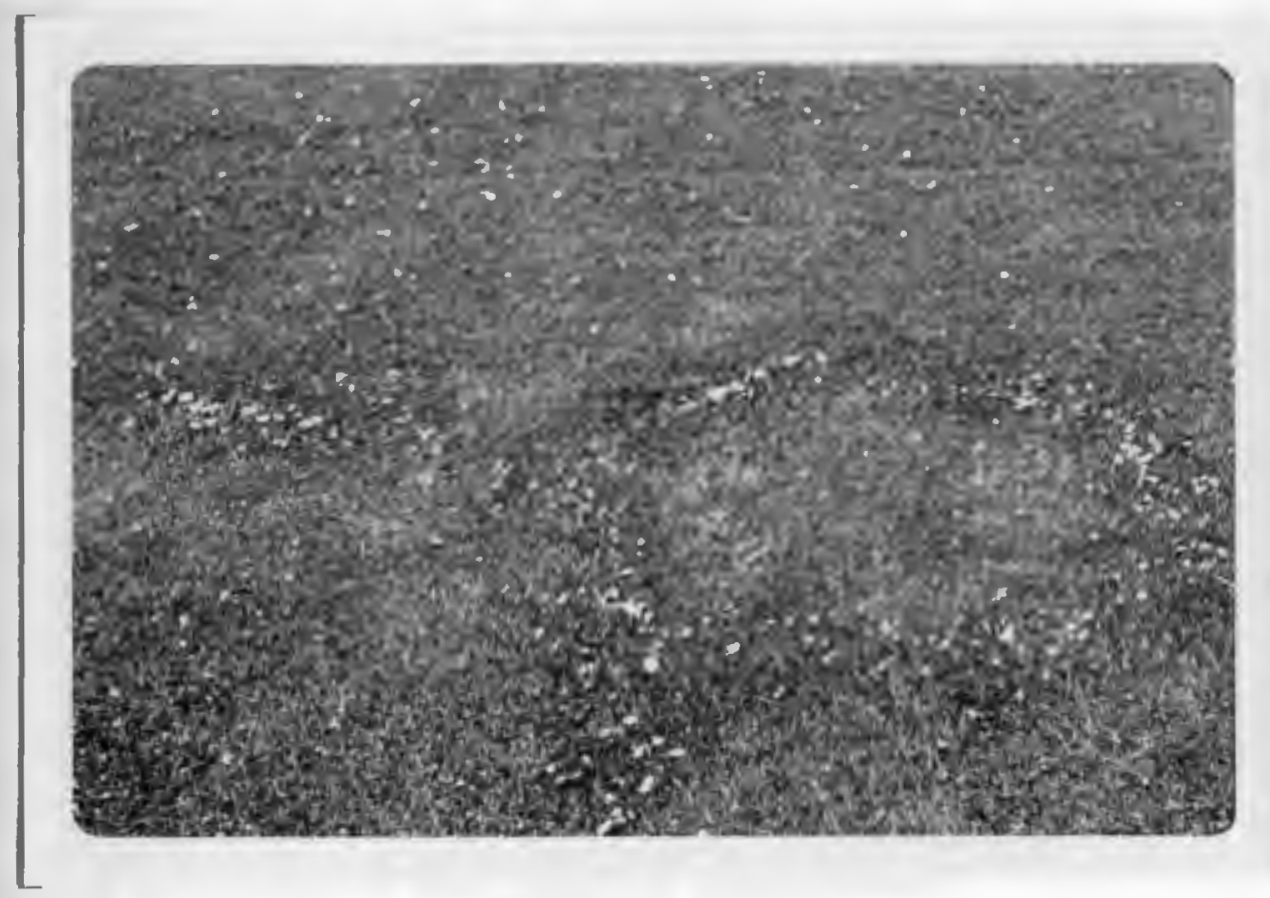

Marasmius fairy ring in bluegrass turf 
TABLE OF CONTENTS

Page

I. INTRODUCTION . . . . . . . . . . 4 4

II. REVIEW OF IITERATURE . . . . . . . . . 6

III. GENERAI MATERIAIS AND METHODS . . . . . 20

IV. CHEMICAI CONTROI OF MARASMIUS OREADES

FAIRY RING . $\bullet \cdot \cdot \cdot \cdot \cdot \cdot \cdot \cdot \cdot \cdot \cdot \cdot \cdot$

24

V. THE INFLUENCE OF TEMPERATURE ON THE IINEAR GRONTH OF MARASYIUS OREADES AND PYTHIUM ARTOTROGUS $\bullet \cdot \bullet \cdot \bullet \cdot \bullet \cdot \bullet \cdot \bullet \cdot \bullet \cdot \bullet$

VI. THE INTLUENCE OF HYDROGEN-ION CONCENTRATION ON LINEAR GROWTH OF MARASMIUS OREADES AND

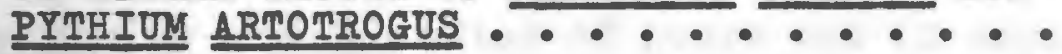

VII. THE ANTAGONISM OF PYTHIUM SPECIES TO

AGARICUS BISPORUS AND MARASMIUS OREADES. -

VIII. THE NATURE OF ANTAGONISM OF PYTHIUM ARTOTROGUS TO MARASMIUS OREADES ...

IX. ANTAGONISM OF VARIOUS PYTHIUM SPECIES BY PYTHIUM ARTOTROGUS . • • • • • • • •

X. PATHOGENICITY OF PYTHIUM SPECIES TO POUR AGROSTIS SPECIES ....... . .

1. Pythium injury to germinating Agrostis seeds . . . . . . . . . . • • •

B. Pythium injury to Agrostis seedings . . 55

XI. DISCUSSION . . . . . . . . 58

XII. CorrclusIONS ............... 69

III. SUMMARY ................ 71

IIV. IITERATURE CITED ............. 73 
1. Cross section diagram of a falry ring caused

by Marasmius oreades . . . . . . . . . 8

2. Effect of temperature on linear growth of

Pythium artotrogus and Marasmius oreades

after 48 hours and 8 days, respectively... . 33

3. Effect of hydrogen-ion concentration on

linear growth of Pythium artotrogus and

Marasmius oreades after 48 hours and 10 days, respectively .. . . . . . . . . . 36

4. Diagram of method used to determine the degree

of growth reduction of Agaricus bisporus and

Marasmius oreades by Prthium species . . . . 38

5. Camera lucida drawing showing the relation of

Pythium artotrogus to hyphae of $\underline{P}$. ultimum

and P. debaryanum ........ 50 


\section{IIST OF TABLES}

Table

1. The influence of funglcide treatment on

M. oreades fairy ring, 1963 . . . . . . 28

2. The degree of growth retardation of Agaricus

bisporus and Marasmius oreades by Pythium

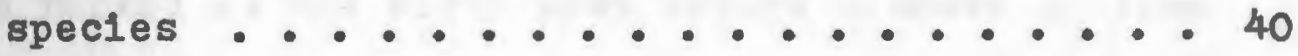

3. Relative pathogenicity of Pythium species to germinating seeds of Agrostis species . . . 54

4. Relative pathogenicity of Pythium species to roots of Agrostis species. . . . . . . 57 


\section{INTRODUCTION}

Fairy ring is a disease which causes a considerable amount of damage to varlous grasses throughout the world. Any of a number of fungl may cause the injury, but Marasmius oreades Fr. Is the most common one producing the disease in lawns and golf greens. The "ring" increases in size each year, thereby increasing the area of damaged turf. Fairy rings have been reported to be the most commonly encountered disease of lawn turf in North America. Marasmius falry ring has been ranked as the sixth most severe disease of lawn grasses (17).

Control of this disease is usurily difficult and expenaive. Methods of control that involve the application of fungicides by drenching them into. the turf have not proved to be satisfactory (3). Recommended control methods are either fumigation of the soll which also kills the vegetation, or the removal of the affected turf and replacing 1t with uncontaminated so1l. After use of elther method, reseeding or resodding of the area is required.

Recently Sinden and Schisler 1solated a species of Pythium in Pennsylvania inhibltive for the growth and development of the commercial mushroom, Agaricus bisporus (Lange) Singer. The same fungus was later 1solated by sinden from mushroom beds in the Netherlands and England indicating that 1t is rather widespread in its occurrence in association with the commercial mushroom. The fungus was identified as Pythium artotrogus (Mont.) dBy. by Fergus (15). Species of 
Pythium usually are not considered to be very antagonistic towards other fungi. However, several Pythium species have been shown to be parasitic on other Pythium species $(13,14)$. Agarlcus b1sporus (synonyms A. campestris Fr. and Psall10ta campestris (L.) Fr.) has been reported as the cause of fairy ring in turf. Since Pythium artotrogus has been shown to inhibit the growth of this fungus in mushroom compost beds, it was decided to determine whether this Pythium specles could be used for blological control of the fairy ring disease of turfgrasses. Marasmius oreades was selected for this study to represent a typlcal fairy ring fungus, since it is commonly encountered in turegrass areas in Rhode Island. In order to determine whether $\underline{P}$. artotrogus has the potential to be used for falry ring control, the nature of the antagonism must f1rst be determined. To accomplish this, certain experimentation was required. A study of the effect of temperature and hydrogen-1on concentration on the growth

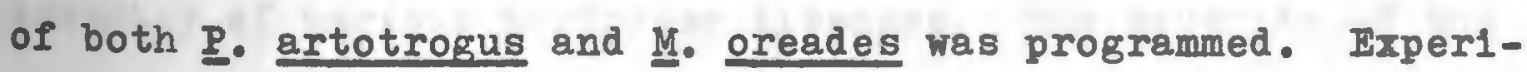
ments to determine the degree and type of antagonism exhib1ted by $\underline{\underline{P}}$. artotrogus towards $\underline{\underline{A}}$. b1sporus, $\underline{\underline{M}}$. oreades and other Pythium species were designed. Pathogenicity tests on grass seeds and seedlings were planned with $\underline{\underline{P}}$ artotrogus and congeneric forms. 
Fungus fairy rings are world-wide in distribution and may be found in lawns, golf courses, sports flelds, pastures and other grass habitats. They are caused by a number of different besidiomycetes and a few ascomycetes. Couch (12) lists twenty genera of fung1, while Shantz and Plemelsel (31) list twenty-four different genera that cause falry rings. Since they are such diverse fungl, they are found in assoclation with nearly all the common grasses, especially those used for lams and pastures.

The economic 1mportance of this disease is very difficult to assess. People most concerned with controlling the disease, however, are those interested in maintaining good quality turf for recreational purposes. Gould (17) recently conducted a survey in whlch turfgrass pathologists from thirty localities throughout North America reported on the severity of various turfgrass diseases. The severity of the twenty-four diseases reported were separated into two categories on the basis of grasses maintained as laws and those maintained as golf greens. In lawn turf, falry ring was ranked as more severe than any other disease, while that caused by Marasmius spp. rated as sixth in severity. However, in golf putting green turf fairy ring was indexed as fourth and the Marasmius falry ring was ranked eighth in sever1ty.

The falry ring syndrome is commonly characterized by a - Ircular band of grass that is greener and faster growing 
than the surrounding grass. Mushrooms or puffballs are frequently observed elther in or at the advancing edge of the green ring. The diameter of the falry ring varies greatly from a few to over two hundred feet. On the average, however, they range from three to twelve feet and increase in diameter each year.

Shantz and Piemeisel (31) classified fairy rings into the following three basic categories: type I, rings marked by a zone of dead grass; type II, rings marked only by a zone of stimulated grass; and type III, rings which produce no noticeable effect on the grass. In each of the three categories sporophores of the fungus may be present or absent depending on the season of the year and environmental factors. Marasmius oreades falry ring belongs in the type I category.

A varasmius oreades falry ring in cross section, as drawn by Molliard (27), is illustrated in Figure 1. Zone I represents the central area inside the ring. Zone II represents an inner ring of stimulated grass that is greener than the grass in zone I. A band of dead grass is represented by zone III, in which the basldiocarps are produced. Zone IV represents an outer band of stimulated grass. The degree of stimulation is greater and the grass is greener in zone IV than in zone II. Zone $V$ represents the surrounding unaffected normal grass. Molliard stated that in the spring and early summer, zones II, III and IV are a single wide ring of stimulated grass and that zone III develops in late summer and early fall. The mycelium of the fungus was found primarlly 


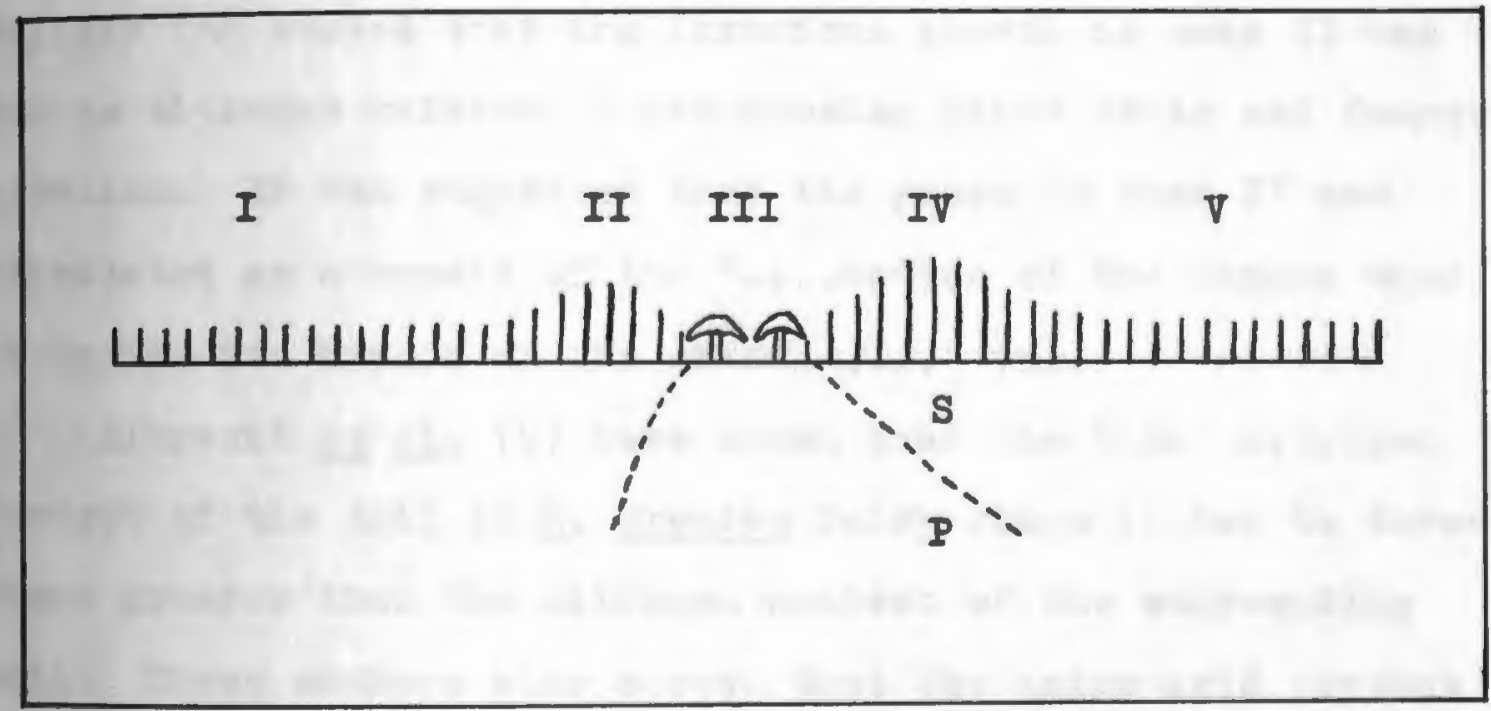

Figure 1. Cross section diagram of a falry ring caused by Marasmium oreades. I. Center of fairy ring. II. Area of stimulated grass. III. Area of dead grass. IV. Area of stlmulated grass, $P$ - zone of low (7\%) molsture, S - zone of h1gher (21\%) molsture. V. Unaffected grass outg1de of fairy ring. Redrawn from Molliard (27). 
in zones II, III and IV with the joungest mycelium in zone IV.

The stimulation of the grass was once thought to be due to atmospheric nitrogen being assimilated by the fungus and then released to the so11. Lawes et al. (22) showed that the fungus was able to ut1lize organic nitrogen from the so1l and subsequently release "manure" for the grass. BaylissElliott (5) stated that the luxurlous growth in zone II was due to nitrogen release by decomposing plant roots and fungus mycelium. It was suggested that the grass in zone IV was stimulated as a result of the "....action of the fungus when 1t begins 1ts attack on the grass, ...." (5).

Albrecht et al. (2) have shown that the total nitrogen content of the soil in M. oreades falry rings is two to three times greater than the nitrogen content of the surrounding so11. These authors also showed that the amino acid content of the soll was generally greater in fairy rings than in normal so1l. Ther found that the ratio of a given amino acid between the two regions varied with the season of the jear. The greatest difference occurred during the summer. In studies conducted with M. oreades grown on straw, Ilndeberg (24) showed that the fungus rould decompose 63 per cent of the lignin, 91 per cent of the cellulose and 83 per cent of the purfural-rielding substances of the substrate. According to Molliard (27), wilting and death of the grass in zone III is due to a combination of a lack of water and an accumulation of ammonium compounds in the soil. In 
the $\underline{x}$. Oreades fairy ring studied by Molliard (F1gure I) the molsture content of the soll in zones $I, I V-S$ and $V$ was $2 I$ per cent, while the moisture content of the soll in zone III was 5 per cent, and in zone IV-P was 7 per cent. The highest concentration of ammonium compounds, $80 \mathrm{mg}$. per $100 \mathrm{~g}$. of dry soil, was found in zone III, while the amount of ammonium compounds was about $38 \mathrm{mg}$. per $100 \mathrm{~g}$. of dry soil in zones I and T. Holliard stated that roots weakened under these conditions were susceptible to invasion by the fungus.

Bayliss-Elliott (4) reported that soil taken below the dead zone causes the root tips of healthy grass plants to turn brown or black within twenty-four hours. This same toxic reaction occurred after using a weak extract of the basldiocarps. The active principle was lost, however, when heated to $100^{\circ} \mathrm{C}$. Further evidence showed that an active peptonizing enzyme, peptase, which digests vegetable fibrin, and a peptolytic enzyme, ereptase, which digests Witte peptone, were produced by $\underline{\underline{M}}$ oreades. Having thus weakened the plant, the fungus was credited with invasion of the grass roots causing the root tips to become stunted. The mycelium penetrated all of the soft parenchymatous parts of the root, leaving only the axial stele uninvaded. When the plant was almost dead, the mycellum Invaded the leaves. Plants killed in this manner were:

Agrost1s stolonifera, bentgrass Anthoxanthum odoratum, sweet vernalgrass Arena flavescens, yellow oats 
Dactylis glomerata, orchardgrass

Holcus lanatus, velvetgrass

Iolium perenne, English ryegrass

Plantago lanceolata, buckhorn

Poa pratensis, Kentucky bluegrass

Trifollum repens, white clover

In studies conducted bJ Shantz and Plemeisel (3I) on

fairy rings caused by Agaricus tabularis it was concluded that death of the vegetation was caused solely by the lack of soll water in the dead zone and not by parasitism or toxic secretions of the fungus. The soil beneath this zone was found to be extremely difficult to wet, even when the equivalent of two inches of rain was applied to the surface.

Two diatinct hypotheses have been formulated to explain the death of vegetation in this dead zone. Shantz and Piemeisel (31) believed that death occurred solely as a result of the lack of water in zone III (Figure I). BaylissFlliott (4) on the other hand believed that the grasses died primarily as a result of fungus pathogenesis. Molliard (27) took a somewhat neutral stand by stating that the dead zone was due to a combination of lack of water and an accumulation of ammonium salts.

More recently Lebeau and Hawn (23) have shown that mycelium of $M$. oreades when grown in liquid culture produces hydrogen cyanide. These authors also demonstrated that hydrogen cyanide $1 \mathrm{~s}$ present in the dead grass zone of Marasmius fairy rings, but not in the soll surrounding the rings. 
Iike Nolliard, these authors take a neutral stand by stating that : "Very small quantities of HCN probably affect the growing tips of young grass roots and may initiate the disease. This view does not detract from the hypothesis that in the final stage of pathogenesis the plants die from drought caused by such a heavy growth of the fungus in the soll and the water cannot penetrate to the grass roots."

A fairy ring usually originates from a spore or from mcellal fragments which have been deposited in a favorable location by wind, or in some cases, by mowing machines. After a suitable perlod of growth, and when other factors are favorable, the resulting mycelial mass will produce fruiting stmuctures. The mycelium continues to grow in an outward direction each year. As the falry ring gets larger, the mycelium in the center of the ring apparently dies. Attempts at isolation from this zone fall to jield the fungus causing the fairy ring. Furthermore, one seldom finds a fairy ring inside another fairy ring except when the outer ring has an extremely large diameter. Th1s outward growth phenomenon has been explained as being due to the fungus exhausting the arallable nutrients within the substrate. Bayliss-Elliott $(4,5)$ observed that when two Marasmius fairy rings met, the mycella at the points of contact appeared to die. She also showed that media previously used by $\underline{M}$. oreades would not support normel growth even when fortified with fresh nutrients. From this evidence she concluded that the fungus produced toxic metabolites in the substrate which prevented 
further growth of the mycelium. This evidence was used to explain the outward growth of the fungus.

The rate of advance of Marasmius falry ring has been shown by Baylise-Elliott (4) to range from a minimum of three inches to a maximum of 13.5 inches per year.

Wilkins and Patrick (37) considered $\underline{M}$. oreades as a summer mushroom which produced basidiocarps from May through october. The sporophores developed more abundantly on a clay soll having a pH of 5.8 to 6.3 than on a sandy soll where the $\mathrm{pH}$ was 4.6 to 5.0 . They were never observed on a soll composed predominately of chalk with a pH of 6.8 to 7.1 .

While studying a Marasmius fairy ring on grass heath so1ls in England, Warcup (36) observed that the mycellum of M. oreades was not v1sible to the naked eje as 1 t was in larns. The mycelium was restricted to a zone near the surpace, not exceeding a depth of four inches and with a lateral distribution of $81 x$ to twenty-four inches. He also reported (36) that there was a pronounced change in the fungal flora

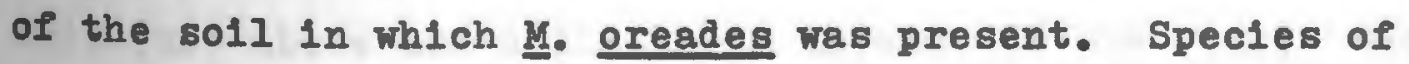
Absidia, Fusarium, Gliomastix, Penfcillium, Phoma,

Yortierella, Stysanus and Trichoderma were commonly found In normal soil, but were absent or only rarely found in the mycelial zone of Marasmius oreades. Penicillium nigricans and cephalosporium sp. were common to both soils. Although rarely found in normal so1l, Grmnoascus subumbrinus and 1rachnlotus sp. were commonly found in solls inhabited by ․ oreades. Other fungl found associated with this falry 
ring fungus were Chaetomium spp., Sordaria sp., Thielaria sp. and Byssochlamys nivea.

The control of falry ring has proved to be quite diffleult, even with the extremely potent funglcides that are eurrently avallable. After her study of $\underline{\underline{y}}$. oreades falry ring, Bayliss-Elliott (5) stated that "....1f the grass in front of an advancing ring is manured with ordinary stable manure the rings die out....." No other reference has been found in the literature concerning the use of manure for the control of falry ring. However, Buller (7) has reported that a mixture of one part horse manure to one part cow manure was used successfully for the cultivation of mushrooms of $\underline{\text { M. }}$. oreades. These seeming conflicting reports ralse doubt on the value of manure as a treatment for the control of fairy ring.

Shantz and Plemeisel (31) stated that when methods 1nvolving digging up the soil are not practicable, then the application of a fungicide, such as Bordeaux Mixture, to the soll just above and a little in advance of the ring, "should" be effective in controlling the disease. From observations made in Rhode Island, Howard et al. (21) stated that organic cadmium funglcides appear to inhibit the formation of some mushrooms. Dolomitic limestone or magnesium salts also have been found to inhibit the development of basidiocarps of the cultivated mushroom (21).

Oouch (12) has reported that appreciable reduction in the damage caused by falry ring may be obtalned by the 
suppression of fungal growth. This was done by pouring phenyl mercury acetate or cadmium-containing fungicides mixed with a wetting agent into small holes four inches deep. These holes were twelve inches apart. The area was then arenched with water equivalent to at least one inch of rain. In order to obtain complete control of this disease, however, eradication of the fungus was required. This may be accomplished by removal of the soll and turf to a depth twelve inches and eighteen inches on elther side of the stimulated zone. Fumigation of the soll with elther formaldehyde or methjl bromide will also eradicate the fungus.

Llexander (3) tried to control a fairy ring caused by a apecies of Iepiota by use of a wetting agent applied in oneinch holes eighteen inches deep and six to eight inches apart. This treatment was followed by a solution of bioblorlde of mercury. An examination of the treated fairy ring a jear later revealed that the diameter of the ring had increased thirty-two to thirty-four inches. Complete control of the falry ring was obtained only when the soll was removed to a depth of twenty-eight inches and at least twelve inches in advance of symptoms. The hole was then filled with uncontaminated soll and the surface resodded.

In laboratory studies with $\underline{M}$. oreades Iebeau and Hawn (23) found that the antibiotics Acti-dione, Rimocidin, endomycin and griseofulvin at $10 \mathrm{ppm}$. all inhibited mycelial growth.

Recently Fergus et al. (15) reported 1solating a fungus 
in Penzsylvania and in the Netherlands which completely inhibited the growth of the cultivated mushroom Agaricus bisporus. The antagonistic fungus was 1dentified as Prthium artotrogus. A preliminary attempt was made by the authors to determine the nature of this antagonism. Cylinders filled with compost were inoculated with A. bisporus at one end and with P. artotrogus at the other end. Once the mycella of the two fung1 met, both organlsms stopped growing. Pythium artotrogus is one of the few Prthium species in which no asezual spore (sporanglal) stage has been demonstrated. This fungus belongs to a group of Pythium species which are characterized by echinulate oogonia. It was originally descrlbed by Montagne (6) as a pathogen on potato tubers and given the name Artotrogus hydnosporus. Smith (33) considered the spiny structures of this Pythium as the sexual stage of the potato bl1ght fungus Phytophthorg (Peronospora) 1nfestans.

In h1s monograph of the genus Pythium, Middleton (26) reported that $\underline{P}$. artotrogus has been 1solated from the following plants in the localities cited:

Ananas comosus Merr., pineapple, Hawail Aplum graveolens I. var. dulce, celery, Ingland Arabis alpina $I_{0}$, rockcress, The Netherlands Brassica oleracea I. var. botrytis, cauliflower, Germany Cajanus cajan Millsp., pigeonpea, Hawa11 Canavalia ensiformis DC., Jackbean, Hawa11 Ipomoea batatas Lam., sweet potato, Hawail Ircopersicon esculentum Mill., tomato, Hungary 
Nymphaea candida Presl., waterlily, Bohemia

Pan1cum purpurascens Radi1, Para grass, Hawa11

Phaseolus vulgaris I., garden bean, Hawa11

Pinus banksiana Lamb., Norway plne, United States

P. nigra var. austriaca Aschers. and Graebn., Austrian pine, The Netherlands

P. ponderosa Dougl., western yellow pine, United States E. resinosa Ait., red pine, Onited States

Pseudotsuga taxifolia Britt., Douglas-11x, The Netherlands

Raphanus sativus I., garden radish, Sweden

Saccharum officinarum I., sugar cane, Hawa11

Solanum tuberosum I., potato, Ingland, France, Germany, India

Spinacia oleracea I., spinach, The Netherlands

Vigaa sinensig I., cowpea, Hawail

Viola tricolor I., pansy, Norway

Matthews (25) 1solated P. artotrogus from water in South Carolina.

Although P. artotrogus has been isolated from the tissues of many plants, this does not necessarily mean that the fungus is a pathogen to all of them. Olinton (9) found P. artotrogus on grape, but considered it a secondary invader Iollowing infection by another pathogen. Pythium artotrogus was 1solated by Hartley (18) from damped-off Plnus resinosa and P. banksiana. The isolate was considered to be a potential parasite on pine seedlings, but not of any general importance. Pythium apecies have not been considered to be 
particularly antagonistic to other fung1. However, there are reports in the literature by Drechsler $(13,14)$ concerning the parasitic and antagonistic activity of three Pythium species on other congeneric forms. It has been show that $\underline{\underline{P}}$. $011 \mathrm{gan}-$ drum parasitizes $\underline{P}$. arrhenomanes, $\underline{\text { P. butler1, }}$. debaryanum, P. graminicolum, P. helicoldes, P. irregulare, $\underline{P}$. mammillatum, $\underline{P}$. oedochilum, $\underline{P}$. palingenes, $\underline{P}$. Salpingophorum, $\underline{P}$. splendens and P. ultimum. pythium acanthicum was reported to parasit1ze $\underline{\underline{P}}$. anandrum, $\underline{\underline{P}}$. marsiplum and $\underline{\underline{P}}$. mastophorum, while $\underline{\underline{P}}$. periplocum parasitized $\underline{\underline{P}}$ anandrum and $\underline{\underline{P}}$. marsipium. It is interesting to note that these three parasitic Pythium species all produce echlnulate oogonia.

Drechsler $(13,14)$ observed that the hyphae of the parasitic P. ollgandrum first colled around the hyphae of the host followed by penetration. Once penetration had occurred, the parasite grew lengthwse through the mycelium of the host causing degeneration of the protoplasm. Occasionally this internal mycelium branched and pushed its way out through the host's hyphal wall.

Drechsler (14) also reported that de Bary in 1881 had consiatently noticed $\underline{P}$. artotrogus in association with $\underline{P}$. debaryanum on garden cress seedlings and that the former could not be cultured separately. De Bary further found $\underline{P}$. artotrogus associated w1th P. debarranum, P. vexans and phrtophthora infestans on potato. De Bary was reported to have offered two alternative explanations for this repeated association: a) p. artotrogus might require substances for 
growth that were absent in his media but are present when grown in association with $\underline{\underline{P}}$. debaryanum; or b) $\underline{\text { P. artotrogus }}$ may subsist as a parasite on the congeneric species. De Bary's observations were later confirmed by Butler in 1902.

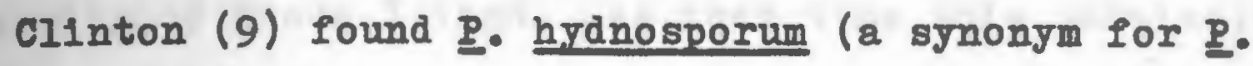
ertotrogus) in association with Phytophthora infestans in rotten potato tubers, and with Phytophthore cactorum causing Infury to pea roots kept in water. On grapes that had been infured by the black rot fungus and the grape berry moth, Prthium artotrogus was observed growing in the fruit tissue, in the "pjonia" of the fungus and in the larvae of the insect. 1ecording to Drechsler (14), Sawada in 1927 found $\underline{\text { P. }}$ artotrogus (synonym P. hydnosporum) in old plant tissue that was infected with Phytophthora cactorum. In the same year Dissman (14) was reported to have found Pythium artotrogus on waterlily along with other Pythium species.

Drechsler (14) stated that many of the workers cited above 1dentifled $\underline{P}$. artotrogus chlefly on the basis of sping oogonia. Middleton (26) Ilsts fourteen species of Pythium wth echinulate oogonia. Since Drechsler found three Prthium apecies with echinulate oogonia (․․ oligandrum, $\underline{\text { P. }}$ acanthlcum and P. periplocum) to be parasitic on other congeneric forms, it was thought that there may have been some confusion as to which Pythium species was actually present. 


\section{GENERAI MATERIAIS AND METHODS}

The 1solate of Marasmius oreades Fr. used in this investigation was obtained in September, 1963, by the author from a basidiocarp in a fairy ring on an athletic field at the University of Rhode Island. At that time this particular fleld contained many fairy rings all of which were caused by y. oreades. The turf was composed primarily of Kentucky bluegrass. The pH of the soll varied from 4.7 to 5.0, while the layer of thatch varied in $\mathrm{pH}$ between 5.0 and 6.0 .

The isolates of Agaricus bisporus (Iange) Singer and Prthium artotrogus (Kont.) dBy. were kindly supplied by Bdith M. Sigel of the Butler County Mushroom Farm, West Winfield, Pennsylvania. Other Prthium species used in this study along wth their source are listed below.

Prthium sp.

P. aphanidermatum (udson) Fitzp.

P. arrhenomanes Drechs. *ITCO

B. debarranum Hesse

E. graminicolum Subrm.

P. 1rregulare Buisman

P. irregulare Buisman

P. Splendens Braun

B. ultimum Trow
Source

Ryegrass

*ITCC

Alfalfa

Alfalfa

So11

Pineapple

$--$

\section{Supplied br}

H. D. Wells, Tifton, Georgia

A. F. Schmitthenner, Wooster, Oh10

A. F. Schmitthenner, Wooster, OhIo

A. F. Schmitthenner, Wooster, Ohio

A. F. Schmitthenner, Wooster, Ohio

H. W. Klemmer, Honolulu, Hawa11

H. . Klemmer, Honolulu, Hawa11

H. B. Couch, Univ. Park, Pennsylvania 
Oultures of Agaricus bisporus and Marasmius oreades were maintained on a 2 per cent glucose medium (32) composed of the following:

$\begin{array}{lr}\text { Glucose } & 20.0 \mathrm{~g} \cdot \\ \text { Potassium monobasic phosphate } & 1.5 \mathrm{~g} \cdot \\ \text { Peptone } & 1.0 \mathrm{~g} \cdot \\ \text { Magnesium sulfate } & 0.5 \mathrm{~g} \cdot \\ \text { Thiamine hydrochloride } & 2.0 \mathrm{mg} \cdot \\ \text { Agar } & 20.0 \mathrm{~g} \cdot \\ \text { Digtilled water to make 1000 ml. } \\ \text { pH } 5.5 \text { after sterilization }\end{array}$

This medium was used because it provided for higher growth rates of the two basidiomjcetes than potato-dextrose agar or potatomdertrose-Jeast agar.

Cultures of Pythium spocies were maintained on potatodextrose agar (PDA) composed of the following:

$\begin{array}{ll}\text { Dextrose } & 10.0 \mathrm{~g} . \\ \text { Agar } & 20.0 \mathrm{~g} .\end{array}$

Broth from $200 \mathrm{~g}$. of cooked potatoes Diat1lled water to make $1000 \mathrm{ml}$.

Both media were sterilized by autoclaving for twenty minutes at a pressure of $15 \mathrm{psi}$ and then aseptically dispensed as 20 to $25 \mathrm{ml}$. aliquots into sterile petri plates.

In studies to determine the effect of hydrogen-1om concentration on the linear growth of Pythium artotrogus and Yarasmius oreades a modification of the 2 per cent glucose medium was employed. Two hundred $\mathrm{ml}$. of one third molar phosphate buffer was substituted for $1.5 \mathrm{~g}$. of 
potassium monobasic phosphate. The phosphate buffer (38) was composed of varlous ratios of phosphoric ac1d, potassium monobasic phosphate, and potassium dibasic phosphate. The potassium monobasic phosphate was added to the medium prior to sterilization. Phosphoric acid and potassium dibasic phosphate were sterilized separately and added aseptically to the medium after autoclaving.

All petri plates were spawned with $5 \mathrm{~mm}$. agar disks bearing mycelium of the fungus. Where possible the agar disks were taken from the edge of the fungal colong. This method provided a falrly constant amount of spawn and thereby reduced the amount of varlation between replications in the experiments.

In order to study microscopically the antagonism by Pythium artotrogus to Agaricus bisporus, Marasmius oreades, and other Pythium species, the fungl were cultured on glass 8lides. The culture slides were prepared by flaming a one by three inch glass slide and placing it on a glass rod support in a sterile petri plate containing a few ml. of sterile water. Agar medium was then aseptically pipetted onto the glass slide so that a thin film of agar gel covered the surface of the slide. The culture slides were spawned with the desired fungl after the agar had solidified. When either 1. bisporus or $M$. oreades was to be studied in association with a Prthium species, the basidiomycete was spawned ten to Ifteen days prior to seeding the Pythium species. A phase contrast microscope and magniflcations of 600 and 1500 
diameters was used throughout this investigation.

Pathogenicity tests of Pythium species on Astoria

colonial bentgrass (Agrostis tenuis Sibth.), Seaside Creeping bentgrass (A. palustris Huds.), Velvet bentgrass (A. canina I.) and Redtop (A. alba I.) were conducted. The artificial light used in these laboratory pathogenicity tests was supplied by four 40-watt General Electric cool white fluorescent lamp8. The light fixtures were suspended above the laboratory bench in such a manner that the distance between the light fixture and the bench surface could be varied and thereby vary the light intensity. In the pathogenicity tests on germinating seeds a light intensity of 100 foot candes was used, while in tests conducted on seedlings a light intensity of 200 foot candles was emplojed.

The seeds of Agrostis species are so small that a tiny Glass dipper was constructed so that one full dipper contained an average of 145 seeds of A. palustris, 97 seeds of A. tenuls, 93 seeds of $A$. canina or 70 seeds of A. alba. Two full dippers of A. alba seed and one full dipper of seed of each of the other Agrostis species were used for each replicate. The seeds for each replicate were placed in an envelope made of folded filter paper. These envelopes were immersed in a 0.5 per cent solution of sodium hypochlorite for one minute followed by four rinses of one minute each in sterile distilled water. The seeds were then air-dried in the fllter paper envelopes overnight at which time they were aseptically scattered over the surface of 1.5 per cent water agar gel in petri plates. 
IV. CHEMICAI CONTROI OF MARASMIUS OREADES FAIRY RING

Fairy ring, as described in the review of literature, often causes severe damage to fine quality turf. Fer field tests of funglcides have been conducted to determine the effectiveness of various products to control the causal agent of this disease. Howard et al. (21) reported observations that organle cadmium compounds and magnesium salts have an inhibitory effect on the development of mushroom sporophores. uppreciable reduction in the damage caused by fairy ring was reported by Couch (12) to be obtained by pouring solutions containing phenyl mercury acetate, or cadmium compounds mixed with a wetting agent into holes four inches deep made at twelve-inch intervals.

In an attempt to rerify these findings and to test other chemicals, field experiments were carried out during the summer of 1962. Established ㅆ. oreades fairy rings located in sports turf on the campus of the University of Rhode Island were selected for the trials. The turf was composed primar1ly of Kentucky bluegrass. The fairy rings were divided Into 36 two-square-foot plots with each plot separated from adjacent plots by a six-1nch buffer zone. Eleven treatments and an untreated control were randomly replicated three times. Before the treatments were applied, the sod was perforated with the tines of a spading fork to a depth of about four inches. Applications were applied as a drench on 
Lugust 22, 1962, at the rate of two quarts of funglcide solution per plot.

Ohemicals and Dosages Tested

\section{Ohemical}

Phenjl mercury acetate (10\%), Vineland Chemical Company
Amount per quart of vater

$0.4 \mathrm{ml}$.

Kethyl arsine oxide, Vineland Chemlcal Company $188.0 \mathrm{mg}$.

SD-345 (2-Propene-1,1-diol diacetate), Shell Development Company

Dexon (p-Dimethylaminobenzenediazo sodium sulfonate 70\%), Chemagro Corp.

Cadmium chloride

$355.0 \mathrm{mg}$.

Copper sulfate

$355.0 \mathrm{mg}$.

Nereuric chloride

$355.0 \mathrm{mg}$.

Dithane $1-40$ (Disodium ethylene bis-dithiocarbamate 97\%), Rohm and Haas Co.

Nagnesium sulfate

$7.1 \mathrm{~g}$ H-3944 $\left(5-0 x^{-4}\right.$ phenyl-5-chloro-1,2 dithiole
$50 \%)$, Hercules Powder Co.

$1.4 \mathrm{~g}$.

MP-89 (1,3-dichloro 5.5-dimethyl hydantoin 98\%) $1.4 \mathrm{~g}$. Nallinckrodt Chemical Works

Control

Since no sporophores developed in the treated areas or control during the season, the results were based on the amount of grass growth stinulation resulting from the influence of the fungus. Perforating the sod with a spading fork caused some injury to the grasses, as well as reducing the amount of stimulation of the turf. 
Within six days after application, the following treatments caused moderate chemical infury to the turf: phengl mercury acetate, methyl arsine oxide, cadmium chloride, copper sulfate, mercurlc chloride, Dithane $1-40$ and magnesium sulfate. Severe injury was observed on the H-3944 and 156-89 plots. After thirty-one days only the phenyl mercury acetate, H-3944 and MP-89 plots exhibited residual chemical injury.

Reduction of the stimulated grass zone of the fairy ring was quite variable among replicate plots of the same treatment. For example, one or two of the replicates showed only slight turf stimulation, while on the third the turfgrass was stimulated as much as the control plots.

The three replicates of phenyl mercury acetate, Dithane $\Delta-40$ and methyl arsine oxide, however, were fairly constant in their reduction of the stimulated zone. For this reason these fungleldes were considered worthy of further testing. During the summer of 1963 a more extensive field experiment was conducted in which seven treatments and a water control were randomly replicated three times. Fach replicate consisted of a complete fairy ring having a diameter of from two to five feet. All falry rings used in the test were located on turf consisting mostly of Kentucky bluegrass and were caused by Marasmius oreades.

Instead of applying the treatments as a drench, as in the previous year, the solutions were injected under pressure into the soil to a depth of twelve inches. Fungicide 
Injections were made with a tree fertilization probe or feeding gun attached by a hose to a Hardie "Town and country" sprajer operated at a pressure of $125 \mathrm{psi.} \mathrm{Injections} \mathrm{were}$ made along the middle of the green band of stimulated turf at intervals of about twelve inches. Each of the fairy rings in this test recelved four to five gallons of solution. On many of the fairy rings, especially those in which there was a dead zone, much resistance to penetration of the soil was encountered when pushing the probe down to a depth of twelve inches.

In evaluating treatments for the control of fairy ring it is difficult to compare one treatment with another unless one completely ellminates the fairy ring. For this reason data were recorded on; 1) the inside diameter of the green stimulated ring, 2) the with of the green stimulated band and 3) the number of sporophores that developed in each ring. Data were taken just prlor to the application of the treatments on July 23, and again one and a half months later on September 5, 1963. The data noted for the three replicates of each treatment were combined and are presented in Table 1. chemical tested

Amount per $10 \mathrm{gal}$.

Control (water)

Wethyl arsine oxide, 10\%, Vineland Chemical Co. $38.0 \mathrm{ml}$.

Phenmad (Phenjl mercury acetate, 10\%), $30.0 \mathrm{ml}$. Yallinckrodt Chemical Works.

Parzate liquid (Disodium ethylene bis-dithiocarbamate, 22\%), E.I. duPont deNemours $77.4 \mathrm{ml}$. \& Company 


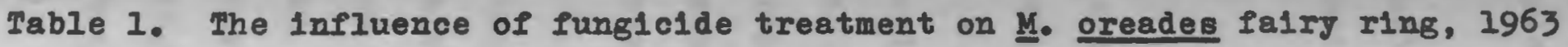

\begin{tabular}{|c|c|c|c|c|c|c|c|c|c|}
\hline Treatment & $\begin{array}{l}\text { *RIng } \\
7 / 23\end{array}$ & \multicolumn{2}{|c|}{$\begin{array}{l}\text { Inner diameter } \\
\text { (Inches) }\end{array}$} & \multicolumn{3}{|c|}{$\begin{array}{l}\text { * Width of green } \\
\text { stimulated zones } \\
\text { (Inches) }\end{array}$} & $\begin{array}{l}\text { *Number } \\
7 / 23\end{array}$ & \multicolumn{2}{|c|}{ of sporophores } \\
\hline Control & 131 & 146 & +15 & 29 & 34 & +5 & 324 & 255 & -69 \\
\hline $\begin{array}{l}\text { Methyl arsine } \\
\text { oxide }\end{array}$ & 93 & 92 & -1 & 24 & 46 & +22 & 265 & 267 & +2 \\
\hline Phenmad & 111 & 125 & +14 & 26 & 43 & +17 & 190 & 245 & +55 \\
\hline $\begin{array}{l}\text { Parzate } \\
\text { Iiquid }\end{array}$ & 124 & 118 & -6 & 22 & 36 & +14 & 247 & 170 & -77 \\
\hline $\begin{array}{l}\text { Malachite } \\
\text { green }\end{array}$ & 123 & 133 & +10 & 27 & 41 & +15 & 328 & 238 & -90 \\
\hline Oalo-clor & 129 & 139 & +10 & 23 & 37 & +14 & 126 & 70 & -56 \\
\hline $\begin{array}{l}\text { Basic aluminum } \\
\text { chloride }\end{array}$ & 101 & 113 & +12 & 25 & 40 & +15 & 279 & 189 & -90 \\
\hline Isothan & 126 & 129 & +3 & 22 & 38 & +16 & 219 & 205 & -14 \\
\hline
\end{tabular}

* Sum of three replicates. 
Salachite green $20.0 \mathrm{~g}$.

calo-clor (Nercurous chloride, 60\%, and mercuric 28.48 . Works

Basic aluminum chloride

Isothan (a mixture of 1 part $75 \%$ dialkyl dimethyl
ammonium bromide to 1 part $75 \%$ alkyl
18oquinolinium bromide), Onjx Chemical
Company $15.0 \mathrm{ml}$.

Except for the vater control, all treatments in addition contained $30 \mathrm{~g}$. of urea and $30 \mathrm{ml}$. of Igepal GA-630 (a nonlonic vetting agent) per 10 gallons of water.

By injecting the chemical solutions directly into the soil, injury was much less severe than that experienced in the 1962 tests, when the treatments were applied as a surface drench. Severe infury was noted with Phenmad and a moderate amount with Calo-Clor, but only around the sites of infection where the solution was forced to the surface.

Table 1 shows that the inside diameter of the fairy Iings decreased with treatments of methyl arsine oxide and Parzate liquid. Realizing that these figures represent the sum of the inner diameters of three replicated fairy rings and that the margins of the stimulated grass zones are not charply defined, the small differences in diameter of the Ings treated with methyl arsine oxide, Parzate liquid and Isothan may be due, in part, to error in measurement. With all the treatments, the width of the green stimulated band of growth was much greater than that of the control fairy 
rings. This phenomenon was due most likely to the urea applied with the funglelde, or to the decomposition of the fungus mycelium. The three fairy ring replicates treated with phenyl mercury acetate had a total of 190 sporophores prior to funglcide application. At the conclusion of the fleld test these same fairy rings had a total of 245 sporophores, or an increase of 55 sporophores. The three control falry rings had a total of 324 sporophores at the beginning of the test, but only 255 sporophores at the conclusion, or a decrease of 69 sporophores. The decrease in the total number of sporophores may be explained by the weekly mowings and continued mushroom production.

As stated above, there is difficulty in evaluating field tests for the control of falry ring unless one or more treatments completely eliminate the fairy ring. This problem is immediately recognized when one observes the data in Table 1. However, the figures seem to indicate that methyl arsine oxide and Parzate liquid warrant further testing. Although phenyl mercury acetate does not appear to have been effective in this field test, further trials are suggested because it has been recommended for a number of years and some success reported. 
V. THE INPLUENOE OF TEMPERATURE ON THE IINEAR GROWTH OF MARASMIUS OBEADES AND PYTHIUM ARTOTROGOS

Pythium species are known to have relatively high growth rates for fung1. In studies of 73 Pythium species and var1eties, Middeton (26) found that optimum growth rates varied from a minimum of $8 \mathrm{~mm}$. per trenty-four hours to a maximum of $51 \mathrm{~mm}$. per twenty-four hours. Basidiomycetes, in general, have much slower grouth rates. It is to be expected, therefore, that . artotrogus had a much greater growth rate than y. oreades. However, in order for P. artotrogus to be effective in halting the growth of $y$ oreades the optimum temperature range for growth of the two fung1 should be somewhat similar.

The effect of temperature on the linear growth of $\underline{M}$. oreades and $\underline{\underline{P}}$. artotrogus was determined by measuring at intervals the diameter of the fungal colony on 2 per cent glucose agar medium. Petr1 plate cultures of $\underline{\text { P. artotrogus }}$ were 1ncubated at $5,10,15,21,25,27,30,35$ and 40 degrees $C$ with five replications per temperature. The $\underline{M}$. oreades cultures were incubated at the same temperatures, except $35^{\circ} \mathrm{O}$ and $40^{\circ} \mathrm{C}$. A $5 \mathrm{~mm}$. agar disk bearing mycellum of the test fungus was transferred to the center of each petri plate. The diameters of P. artotrogus colonies were measured after elghteen hours of incubation at each of the varlous temperatures. Subsequent measurements were recorded at alx-hour intervals up to flfty-four hours. The diameters of the $\underline{\underline{M}}$. oreades colonies were measured at two-day intervals 
up to elght days.

The results of the temperature study are shown in Figure 2. It $5^{\circ} \mathrm{C}$ no growth of elther fungus occurred since the spawn consisted of a $5 \mathrm{~mm}$. agar disk bearing mycelium of the fungus. The optimum temperature for mycelial growth of P. artotrogus was about $27^{\circ} \mathrm{C}$ with an average radial growth rate of $14.5 \mathrm{~mm}$. per twenty-four hours. Marasmius oreades had a similar optimum temperature requirement for mycelial growth. However, its radial growth rate was $1.5 \mathrm{~mm}$. per twenty-four hours. 


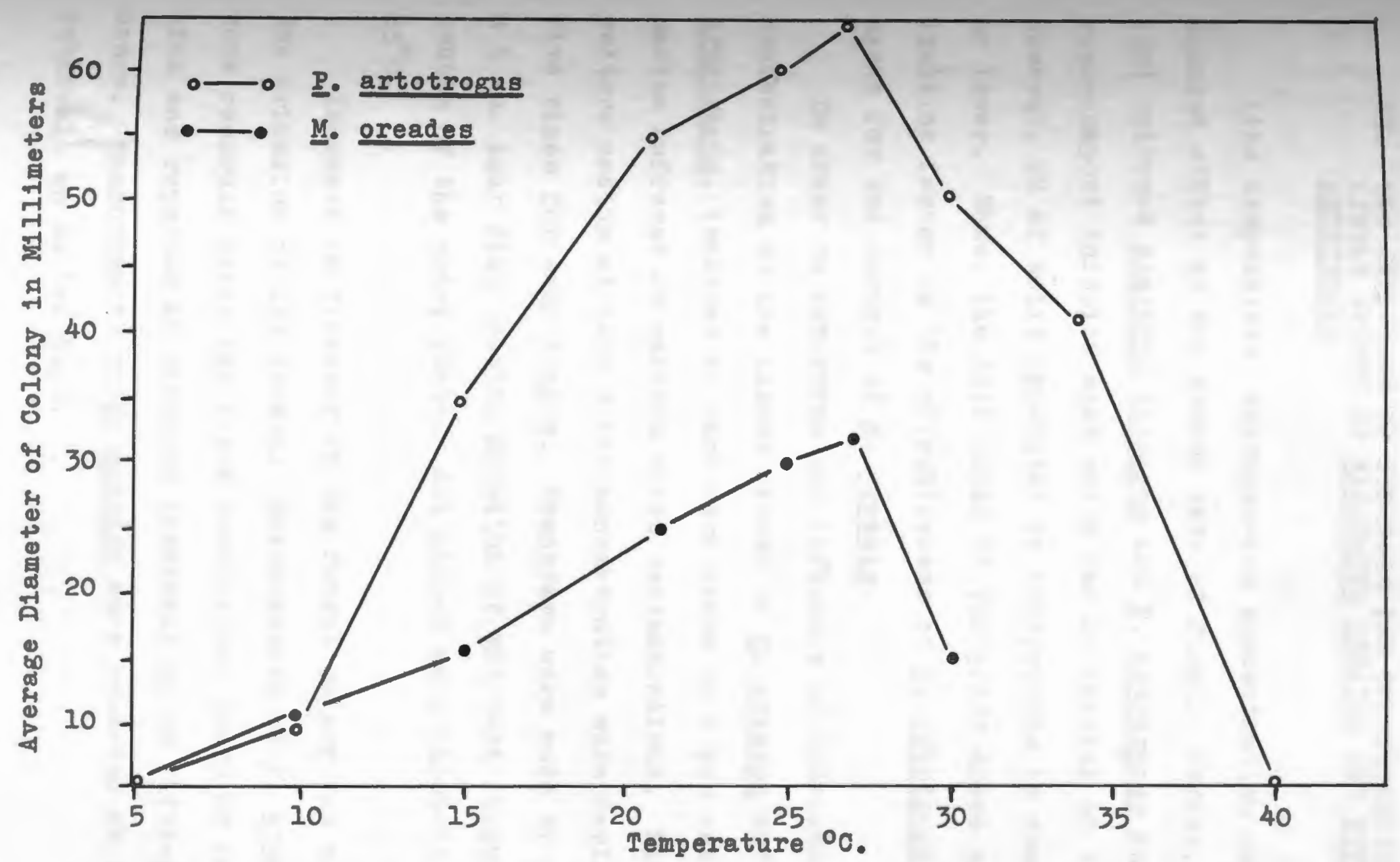

Figure 2. Effect of temperature on Iinear growth of Pythium artotrogus and Marasmius oreades after 48 hours and 8 days respectively. 
VI. THE INFLUENCE OF HYDROGEN-ION CONCENTRATION ON IINEAR GROWTH OF MARASMIUS OREADES AND PYTHIUM ARTOTROGUS

Iike temperature, hydrogen-1on concentration has a pronounced effect on the growth rate of fung1. Fergus, et al. (15) cultured Agaricus b1sporus and P. artotrogus on a mushroom-compost infusion agar which had an initial pH of 7.2 . However, $\mathrm{pH}$ of solls inhabited by turfgrasses is usually 6.5 or lower. Thus, the acid solls of turfgrass areas may be a limiting factor in the effectiveness of $\underline{P}$. artotrogus as an agent for the control of $\underline{\underline{M}}$. oreades.

In order to determine the influence of hydrogen-ion concentration on the linear growth of $\underline{M}$. oreades and $\underline{P}$. artotrogus, 1solates of each were grown on 2 per cent glucose medium buffered at various H-ion concentrations. Plates of culture medium at each H-10n concentration were replicated five times for each fungus. Transfers were made by placing a $5 \mathrm{~mm}$. agar disk bearing nycelium of the test fungus in the center of the petri plate. All plates were incubated at $25^{\circ} \mathrm{C}$.

Increase in diameter of the fungal colony was used as the criterion of 1ts growth. Measurements of P. artotrogus were recorded after the first twenty-four hours of incubation and repeated at six-hour intervals up to fifty-four hours. Measurements on $M$. Oreades were recorded at two-day iatervals up to ten days. 
Colony diameters resulting from each H-1on concentration were averaged for the flve replicates and the mean presented 1n Fgure 3. The optimum $\mathrm{pH}$ for mycelial growth of $\underline{\underline{P}}$. artotrogus was about 5.6 with a minimum $\mathrm{pH}$ value of about 2.5. The optimum $\mathrm{pH}$ for mycelial growth of $\mathrm{M}$. oreades was 5.5 with a minimum and maximum value of about 3.1 and 7.7 , respoct1vely. 


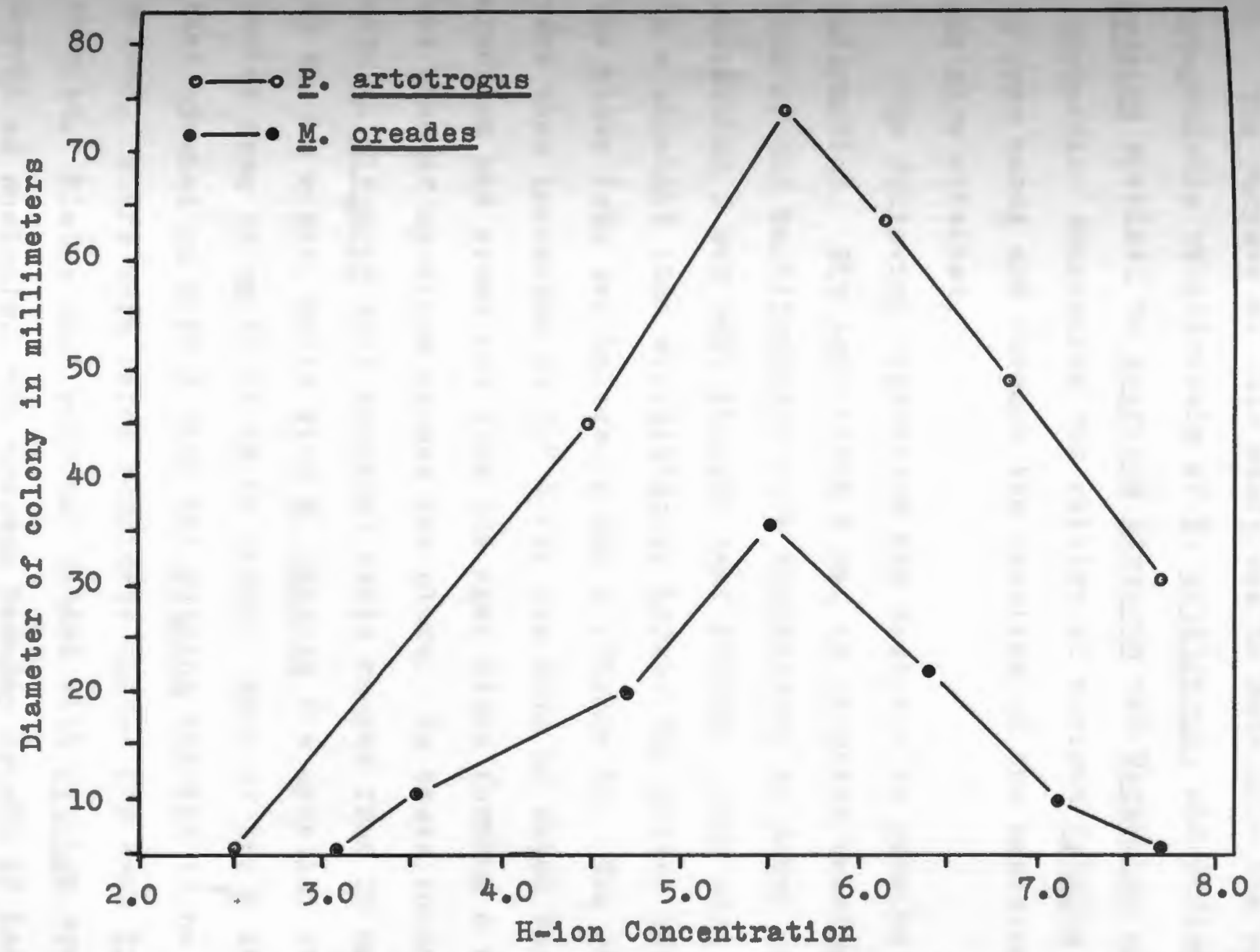

Figure 3. Effect of hydrogen-1on concentration on linear growth of Pythium artotrogus and Maragmius oreades after 48 hours and 10 days respectively. 


\section{THE ANTAGONISM OF PYTHIUM SPECIES TO AGARICUS BISPORUS AND MARASYIOS ORBADES}

The purpose of this study was to determine the possible antagonistic relationsh1p of $\underline{\underline{p}}$. artotrogus, and various other Pythium species, to Agaricus b1sporus and Marasmius oreades. Information concerning the ability of various Pythium species to grow among and through the mycelium of the basidiomycetes was also obtained.

The following experiment was designed to provide this information. S1x agar disks $5 \mathrm{~mm}$. In diameter bearlng mycelium of the basidiomycete were transferred to petri plates contalning 2 per cent glucose agar medium. They were placed in a straight line equidistantly across the center dividing the plate into two halves, $A$ and B (FIgure 4). The plates were then incubated at $25^{\circ} 0$ for ten days by which time the mycellum had grown out from the agar disks forming a continuous band of mycelfum across the plate. In tests conducted w1th $A$. bisporus this mycelial strip ranged from $28 \mathrm{~mm}$. to $48 \mathrm{~mm}$. In w1dth, while w1th $\underline{x}$. oreades the mycelial strip varled from $14 \mathrm{~mm}$. to $26 \mathrm{~mm}$. $1 \mathrm{n}$ wldth. Each of the plates was then spawned on side $\mathbb{A}$ with the Pythium species to be observed. There were three replicate plates for each Pythium species. Plates that were not seeded with Pythium species served as controls. The average ten-day growth of basidiomycete mycellum on side $A$ and on side $B$ of each plate was measured in mm. and recorded. After introducing Pythlum the plates were Incubated for another ten days when the growth 


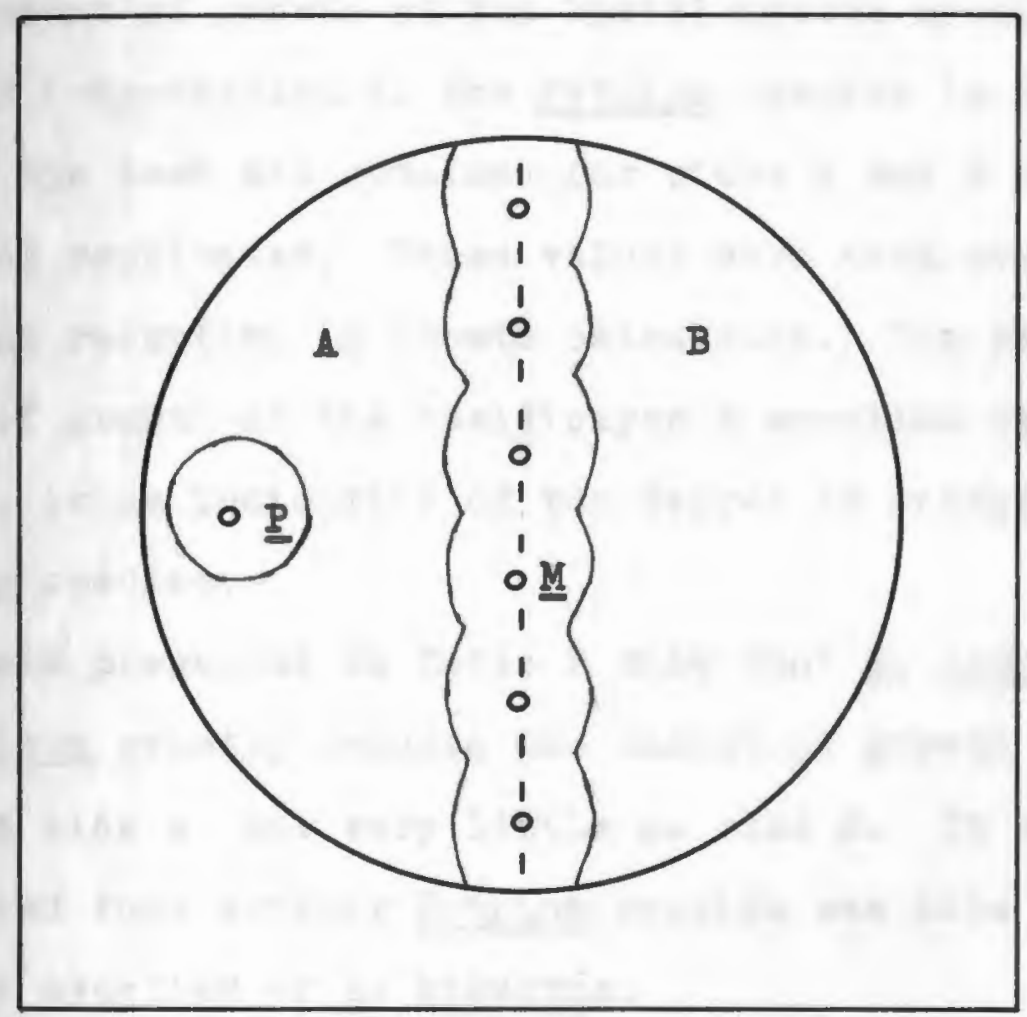

Figure 4. Dlagram of method used to determine the degree of growth reduction of Agaricus b1sporus and Marasmius oreades by Prthium species. Mmycellal band of either Agaricus bisporus or Marasmius oreades. $\underline{P}$ - Pythium species colony. 
of the basidiomycete mycelium on sides $A$ and $B$ were measured again. It was also determined, by visual means, whether the Prthium species grew Irom side A through the basidiomycete njoelium to side $B$.

The amount of growth of the basidiomjcete mycellum from the time of introduction of the Pythium species to the conclusion of the test was obtained for sides $A$ and $B$ in each of the three replicates. These values were then areraged and the per cent reduction in growth calculated. The per cent reduction of growth of the basidionycete mycelium exposed to Prthium sp. is an indication of the degree of antagonism of the Prthium species.

The data presented in Table 2 show that $\underline{\underline{p}}$. artotrogus and P. ultimum greatly reduced the amount of growth of $\mathrm{A}$. bisporus on side $A$, but very little on side $B$. It should also be noted that neither Pythium species was able to grow through the mycelium of $A$. bisporus.

When the antagonism of Pythium species was tested against $\mu$ oreades the results were different. Prthium artotrogus was antagonistic towards $\underline{M}$. oreades mycelium, but did not penetrate through the nycelium. Prthium ultimum was more antagonistic to M. oreades and grew somewhat through the mycelium. However, the Hawailan 1solate of $\underline{\underline{p} \text {. 1rregulare }}$ was the most antagonistic Pythium species tested. Furthermore, this Pythium species grew across the mycelial strip of y. oreades and reduced the amount of growth on side B by a greater degree than d1d P. artotrogus on side $\Delta$. 
Table 2. The degree of growth retardation of Agarlcus bisporus and Marasmlus oreades by Prthium species.

\begin{tabular}{|c|c|c|c|c|c|c|c|c|}
\hline \multirow[t]{2}{*}{ Prthium ap. } & $\begin{array}{c}\text { Retardat1 } \\
\text { growth }\end{array}$ & $\frac{\operatorname{corlous}}{\text { on of }}$ & $\frac{1 \text { spor }}{\frac{\text { Pyth }}{\text { into }}}$ & $\frac{\text { us }}{\text { Ium growth }}$ & 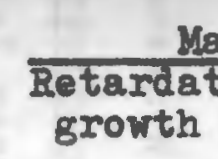 & $\begin{array}{l}\text { resmius } 0 \\
\text { in } \% \text { of } \frac{1}{1}\end{array}$ & $\frac{\text { oread }}{\frac{\text { Evth1 }}{\text { Into }}}$ & $\frac{\frac{d e s}{\text { Ium groyth }}}{\text { area B }}$ \\
\hline & Side A & S1de B & & & S1de A & Side B & 3 & \\
\hline Control & 0.0 & 0.0 & & $\ldots$ & 0.0 & 0.0 & & $-\infty$ \\
\hline P. aphanidermatum & 50.9 & 14.3 & & Yes & 40.2 & 13.0 & & Yes \\
\hline P. arrhenomanes & 0.0 & 15.7 & & No & 42.7 & 9.3 & & Yes \\
\hline P. artotrogus & 72.4 & 15.7 & & No. & 59.8 & 0.8 & & No \\
\hline P. debaryanum & 46.8 & 6.8 & & No & 48.7 & 22.5 & & Yes \\
\hline P. graminicolum & 49.1 & 40.5 & & Yes & 11.8 & 9.3 & & No \\
\hline P. 1rregulare (B) $2 /$ & 57.1 & 6.8 & & No & 88.9 & 69.2 & & Yes \\
\hline P. 1rregulare $(0)$ ? & 43.0 & 14.1 & & No & 34.2 & 13.0 & & Yes \\
\hline P. splendens & 61.3 & 21.0 & & Yes & 48.7 & 9.8 & & Yes \\
\hline P. uItImum & 65.1 & 5.2 & & No & 76.8 & 18.5 & & $\mathrm{Yes}^{3 /}$ \\
\hline
\end{tabular}

$1 /$ See text figure 4.

$2 / H$ and $O$ refer to the Hawallan and Oh10 1solates, respectively.

3 One of the three replicates of $\underline{\underline{B}}$. ultimum grew into area $B$. 


\section{THE TATURE OF ANTAGONISM OF PYTHIUM ARTOTROGUS} TO MARASMIUS OREADES

In order to determine if $p$. artotrogus has the potential to be used as a biological control agent for fairy ring caused by $\underline{M}$. oreades, the nature of the antagonism between the two fungi needed to be determined.

The article by Fergus et al. (15) is the only report in the 11terature concerning the antagonism of a basidiomycete by . artotrogus. These workers showed that growth of the commercial mushroom, A. bisporus, was completely lnhibited by . artotrogus. After an attempt to determine the nature of this antagonism, they stated that following mycelial contact nelther organism grew. It was not determined whether P. artotrogus was parasitic on $\underline{A}$. blsporus, or whether $\underline{P}$. artotrogus produced metabolites which were torlc to 1 ts mycellum.

The nature of antagonism of $\underline{P}$. artotrogus to $\underline{M}$. oreades was determined in the present investigation by observing the two Pungl growling in association with one another on slides coated with potato-dextrose agar. Observations were begun when the mycella of the two fungi were about $5 \mathrm{~mm}$. apart and continued at short intervals until the mycelia of the two fungl had been in contact with each other for several days. Since the agar medium rapidly dried out when left on the atage of the phase contrast microscope for more than an hour, many replacement culture slides were required. 
Actively growing hyphae of both $\underline{M}$. oreades and $\underline{\underline{P}}$. artotrogus on many occaslons stopped growing after a cover glass had been placed on top of the mycellum. Hyphae of A. bisporus were never observed to continue growth after a cover glass had been placed on the mycellum.

The mycelium of $\underline{y}$. oreades is typical of a basidionycete in that the cells are binucleate and the hyphae produce clamp oonnections at the cross walls. The hyphal tip cells were found to be 2 to $3 \mathrm{u}$ in diameter and ranged from less than $250 \mathrm{u}$ to more than $600 \mathrm{u}$ in length. Blunt, needle-shaped, colorless crystals were observed lying across the exterior of the hyphae. These crystals, which were about $1 u$ in width and $3 u$ to $7 u$ in length, were restricted to the older hyphal cells located about 1000 u back from the edge of the colony. The mycelium of $A$. bisporus is not typical of a basidiomycete in that the hyphal cells are multinucleate and clamp connections are not present. The diameter of the hyphae varled from $5 u$ to $7 u$, while the hyphal tip cells varied in length generally from $150 \mathrm{u}$ to $180 \mathrm{u}$. Colorless, needleshaped crystals less than $I u$ in diameter and $7 u$ to $10 u$ long were observed lying on the exterior walls of the hyphae. These crystals were also observed to be restricted to the older hyphal cells, which were about 2000 u back from the edge of the colony.

The cellular contents of the hyphae of both $A$. bigporus and . oreades were difficult to distinguish at magnifications up to 1500 diameters. Streaming of the protoplasm was 
casily observed within the hyphae of $\underline{P}$. artotrogus, but was not observed within the hyphae of $\underline{\Lambda}$. bisporus or $\underline{M}$ - oreades. Therefore, hyphal growth in length was used as the criterion to judge if the mycelium of $\mathrm{k}$ - oreades was alive. The growth rate of hyphal tips of this fungus was observed to be about 2.5 u in five minutes at room temperature. Since $\mathrm{A}$. bisporus was never observed to grow when vlewed through the mlcroscope, it could not be determined with certainty whether or not the hyphae of this fungus was alive.

When the advancing edge of colonies of $\underline{x}$. oreades and P. artotrogus approached each other, the hyphae of each fungus was growling at 1ts normal rate. However, when the hyphal tips of these two fungl were adjacent to each other many hyphal tips of $\underline{\underline{y}}$ - oreades stopped growing. As $\underline{\underline{P}}$. artotrogus continued 1ts growth amongst the mycellum of $\underline{\text { M. }}$ oreades, more hyphal tips of the latter were inhibited.

The only change in the cellular contents of $\underline{M}$. oreades that could be seen when the two fungl were in association with one another, was that the density of 1ts protoplasm appeared to 1ncrease. Hyphae of $\underline{\underline{p}}$. artotrogus were observed to continue their growth for at least two hours. I few hyphal threads exhibited protoplasmic streaming after six to seven days of association wth $\underline{\underline{\mu}}$. oreades. When the two fungl remained in close association for more than a day, the agar in the interhyphal zone began to turn brown, and the hyphae of P. artotrogus became very granular and vacuolated. As the length of time during which the two fungl were in mutual association increased to four days, the hyphae of 
y. oreades became difficult to 1dentify. On these culture slides rectangular crystalline material forming a line or thread was frequently observed in the agar. These threads of cryatalline material appeared to have orlginated from y. oreades hyphae whlch had been lysed.

oogonia of P. artotrogus were produced in abundance in the Interhyphal zone. The hyphae of $\underline{P}$. artotrogus were never observed to enter and parasitize the hyphae of $M$. oreades.

Observations reported earlier in this paper (Table 2) indicate that $\underline{P}$. graminicolum is not very antagonistic (or toxic) toward M. oreades. When this Prthium species was grown in association with $\underline{M}$. oreades on culture slides, the hyphae of the latter remained distinct and did not lyse and form threads of cryataline material. The agar in the interhyphal zone did not become brown. Reproductive structures of g. graminicolum were not produced in the interhyphal zone. Studies of the antagonism of $\underline{P}$. artotrogus to $A$. blsporus were somewhat less productive. This was due to the lack of growth of A. b1sporus after a cover glass was placed on the mycelium. The sequence of events in the antigonism

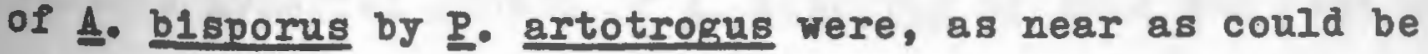
determined, similar to the interaction between $y$. oreades and P. graminicolum. It could not be determined when the hjphae of $A$. bisporus stopped growlng in relation to the position of the hyphas of $\underline{P}$. artotrogus.

The results presented above indicate that the antagonlstic substance of $P$. artotrogus is a toxic metabolite 
Jroduced by the fungus which diffused into the agar. In order to test this hypothesis, $\underline{P}$. artotrogus was grown in potato-dextrose broth aerated by pumping sterile alr through the liquid medium. After seven days of incubation at $27^{\circ} \mathrm{C}$ the culture medium was filtered through a sterile $0.45 \mathfrak{u}$ Millpore filter. The filtrate was then added to sterile melted 2 per cent glucose agar medium. The concentration of the filtrate in the agar medium varied from 0.3 per cent to 50 per cent. One half of this filtrate medium was dispensed directly into sterile petri plates. The remaining half was first autoclaved and then dispensed into sterile petri plates. Lfter the agar had solidified three replicate plates for each fungus at each filtrate concentration were spawned with elther

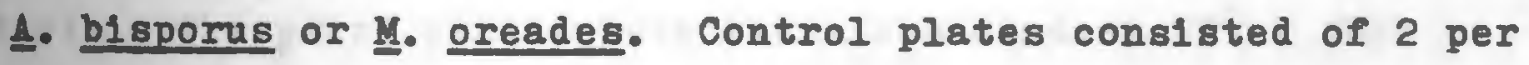
cent glucose medium without $\underline{\underline{P}}$. artotrogus filtrate. After six days of incubation the diameters of the colonies were measured in millimeters and averaged. The unautoclaved 50 per cent filtrate concentration reduced the mycelial growth of $\underline{\Lambda}$. b1sporus by 22.1 per cent and $\underline{\text { oreades }}$ oy 5 per cent. Howerer, the autoclaved 50 per cent filtrate concentration reduced nycelial growth of A. bisporus by 10.2 per cent and M. oreades by 20.6 per cent. All other concentrations of the filtrate reduced the growth of the two fungl to a lesser degree.

In another experiment conducted to determine if metabo-

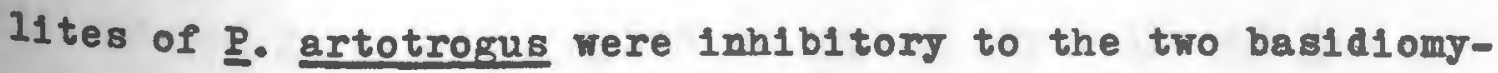
cetes, eight petri plates containing potato-dextrose agar 
were seeded with $\underline{P}$. artotrogus. E1ght other petri plates were seeded with P. graminicolum, and a third group of elght petri plates were left uncontaminated. The petri plates were 1ncribated at $25^{\circ} \mathrm{C}$ for seventeen days. Then the mycellum of the two Prthium species was removed from the agar-gel surface and the petri plates with the residual agar medium were sterilized by autoclaving. Of the elght petri plates in which P. artotrogus had been grown, four were sparned with 1 . b1sporus and four were spamed with $\mathrm{M}$ - oreades. Four of the plates in wh1ch $\underline{\underline{P}}$. graminicolum had been grown were spawned w1th $A$. bisporus and the remaining four spawned with $\underline{M}$. oreades. Of the elght uncontaminated plates four were spamed with A. bisporus and four with M. oreades to serve as controls. The petri plates were then incubated at $25^{\circ} \mathrm{C}$ for nine days after which time the diameters of the colonies were measured in millimeters.

The agar in which P. graminicolum had grown reduced the average amount of mycelial growth of 1 . b1sporus by 42.1 per cent and $\underline{M}$. oreades by 23.3 per cent. Agar in which $\underline{\underline{P}}$. artotrogus had been grown reduced the average mycellal growth of A. bisporus by 34.8 per cent and y. oreades by 69.4 per cent.

Since it was shown that Pythium species deposit metabolite (s) in a substrate that are toric to $\underline{A}$. bisporus and $\underline{\underline{H}}$. oreades, 1t was decided to determine what effect the cultural filtrate of $\underline{P}$. artotrogus had on hyphal tip cells of $\underline{\underline{M}}$. oreades. 
Five hundred ml. of potato-dextrose broth were seeded with E. artotrogus and incubated at $27^{\circ} \mathrm{C}$. Aeration was supplied by pumping sterile air through the liquid medium.

After twenty-four days of incubation, the culture medium was filtered through a sterile 0.45 u Millipore filter. In order to determine if the filtrate would affect growth of hyphal tip cells of $\underline{M}$ - oreades, potato-dextrose agar culture slides were prepared. The growth rate of an average hyphal tip under a standard set of conditions was determined prior to the application of the filtrate. Nfter applying the filtrate to the mycellum, the rate of growth in successive five-minute periods was determined.

It was observed that following the application of the filtrate, the hyphal tip of $\underline{M}$. oreades continued to grow at 1ts normal rate of about 2.5 u per five minutes for the first ten minutes. Growth during the next five minutes was reduced to about 1.5 u. Growth was further reduced to about 1.0 u in the succeeding five minutes, after which time no further growth occurred.

A $10 \mathrm{ml}$. aliquot of the filtrate was then poured into a stoppered test tube and stored at $7^{\circ} \mathrm{C}$. The remaining portion of the filtrate (about $450 \mathrm{ml}$.) was dried under vacuum at a temperature not exceeding $60^{\circ} \mathrm{C}$. The dried flltrate was then redissolved in $25 \mathrm{ml}$. of distilled water and stored at $7^{\circ} \mathrm{o}$.

After twenty-four days of storage at $7^{\circ} \mathrm{C}$, the $10 \mathrm{ml}$. aliquot showed exactly the same degree of blological activity 
toward $\underline{\mu}$. oreades as did the fresh f1ltrate. However, the filtrate that had been dried in vacuo and resuspended did not alter the growth rate of $\underline{M}$. oreades hyphal tips within forty minutes after application.

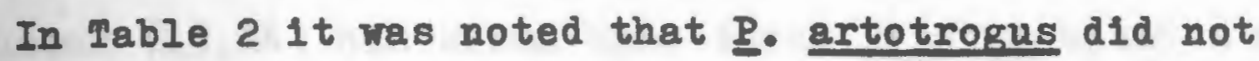
intermingle with and grow through a mycelial band of $\underline{\underline{M}}$. oreades. Therefore, it was decided to determine the nature of the effect of the cultural filtrate of $\underline{M}$. oreades on the hyphal tips of $\underline{P}$. artotrogus. Marasmius oreades was cultured In 2 per cent glucose broth at $27^{\circ} \mathrm{C}$ for 112 days. The culture medium was filtered through a sterile 0.45 u Millipore f1lter. The filtrate was tested for 1ts growth retardation effect on the hjphal tips of $\underline{P}$. artotrogus by the same method

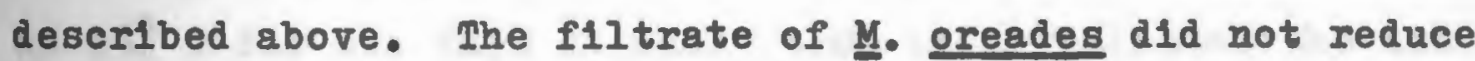
the normal hyphal tip growth rate of about 13 u per minute within seventy minutes after application. 
IX. ANTAGONISM OT VARIOUS PYTHIUM SPECIES BY PYTHIUM ARTOTROGUS

Pythium artotrogus has frequently been found associated with Phrtophthora species and other Prthium species. Drechsler $(13,14)$ has shown that three Pyth1um species with echinulate oogonia are parasitic on congeneric forms. Since P. artotrogus also forms echinulate oogonia, it was decided to determine what effect this fungus has on the hyphae of other Prthium species.

In order to determine the effect of $\underline{P}$. artotrogus on the various Prthium species, culture slides coated with potatodextrose agar gel were seeded on opposite ends with the two specles of Prthium to be studied. The slides were incubated at $25^{\circ} \mathrm{C}$ for two days at which time the mycelia of the two lung1 was observed to have been in mutual contact for more than twenty-four hours.

Prthium artotrogus had no apparent effect on its own hyphae or the hyphae of $\underline{P}$. graminicolum. Hyphae of $\underline{\underline{P}}$. artotrogus were observed to coil around the hyphae of $P$. sphanidermatum, P. arrhenomanes, $P$. debaryanum, P. splendens, P. ultimum and both 1solates of $\underline{\text { P. }}$ irregulare. Colling was at times rather extensive with many gyres, while at other times the colls consisted of only two or three gyres, as (11ustrated in Figure $5 \mathrm{~A}$.

Pythium artotrogus hyphae were observed to enter and to parasitize the hyphae of $\underline{P}$. aphanidermatum, $\underline{P}$. debaryanum, P. splendens, P. ultimum and both isolates of $\underline{P}$. irregulare. 

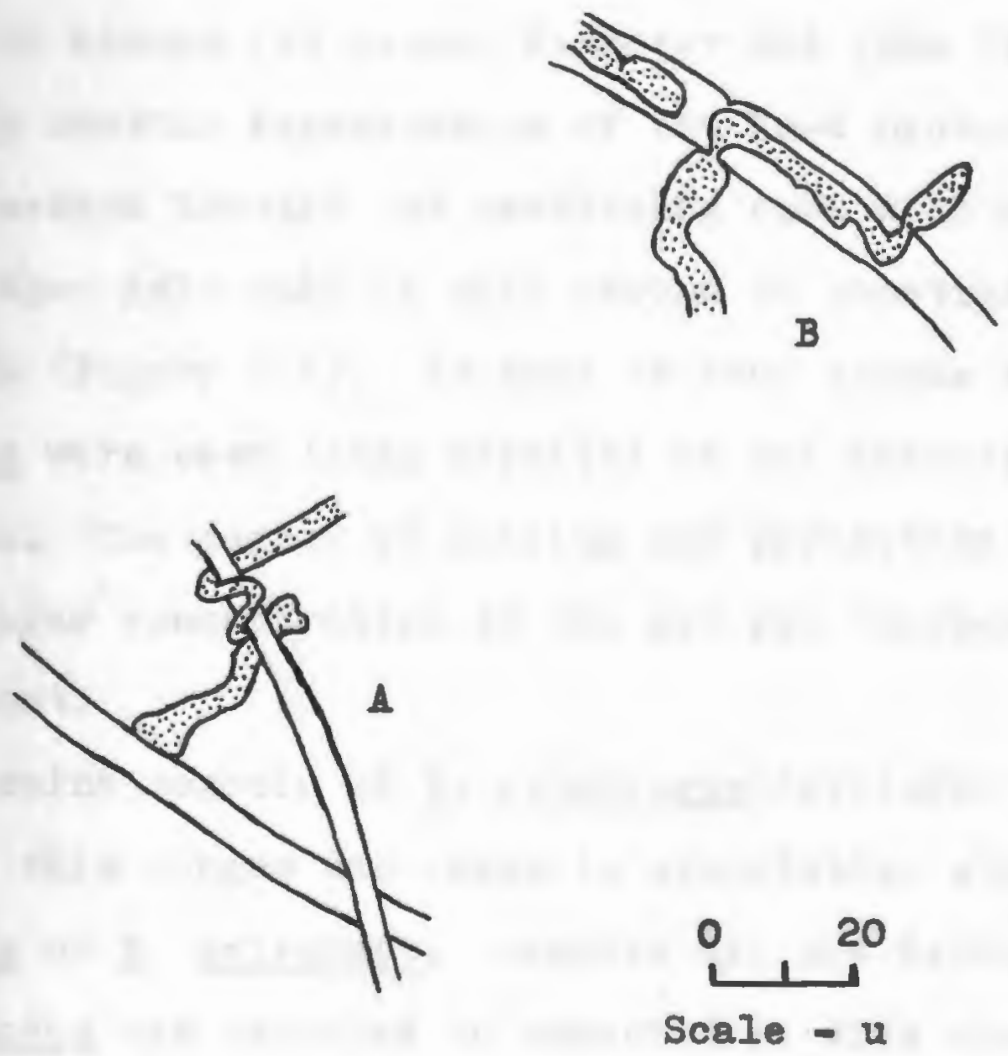

Igure 5. Camera lucida drawling showing the relation of Pythium artotrogus to hypha of $\underline{P}$. ultimum and P. debaryanum. A) P. artotrogus forming simple colis around the hyphae of ?. UItimum. B) P. artotrogus penetrating and growing through the hyphae of $\mathbf{p}$. debaryanum. 
When encountering a susceptible hypha, the hyphal tip of $P$. artotrogus formed a swollen structure analogous to an appressorlum (Plgure 5 B). Penetration of the host was accomplished by means of a narrow infection peg originating from the appressorium. Once inside the host hypha, the invading hypha enlarged to almost its normal diameter and grew lengthwise, cparently causing degeneration of the host protoplasm. Often it then emerged through the enveloping host wall and grew out into the agar gels only to coll around or penetrate another host hypha (Flgure 5 B). As many as four hyphae of $\mathrm{P}$. artotrogus were seen ljing parallel to one another within a host hypha. The degree of colling and parasitism was reduced when the agar concentration of the gel was increased above 1.5 per cent.

The spiny oogonia of P. artotrogus developed within two days when this fungus was grown in association with $\underline{P}$. debaryanum or $\underline{P}$. Splendens. Oogonia did not develop when P. artotrogus was cultured in association with the other Pythium species. 
X. PATHOGENICITY OF PYMHIUY SPECIES TO FOUR AGROSTIS SPECIES

In a survey of turfgrass pathologists throughout North America, Gould (17) recelved reports that diseases caused by Pythium species were the sixth most infurious to golf putting green turf. Since several pythium species are known to damage turfgrasses severely, it was necessary to determine whether $\underline{\underline{P}}$. artotrogus would Injure grasses used for lawns and sports turf. The pathogeniclty of the various pythium species was tested in the laboratory on germinating seeds and seedlings of four Agrostis species.

Agrostis alba I. (redtop) is commonly grown in lawn, along highways and alrports in the cool regions of the United States and Canada. Agrostis canina I. (Velvet bentgrass) may be found in meadows and golf putting greens from Newfoundland southward to Tennessee and as far west as Michigan. Agrostis palustris Huds, var. Seaside (creeping bentgrass) is used Drimarliy for putting greens, falrways, and lawns. Th1s species is largely restricted in the United States to the northeastern and northwestern states. Agrost1s tenuls S1bth. var. Astorla (Colonial bentgrass) is used for lawn, golf putting greens, and tennis courts in the northeastern and northwestern portions of the United States (20).

1. Prthium infury to germinating Agrostis seeds.

In order to determine the degree of pathogenicity of the various Pythium species to germinating seeds of Agrostis species, seeds were germinated on 81.5 per cent agar-water 
gel in petrl plates in the presence of the fungus. Each petrl plate was spawned with three $5 \mathrm{~mm}$. agar disks bearing actively growling mycellum placed equidistant on the gel surface. Petri plates of agar-water gel contalning seed, but without the fungus, served as checks on germination. Each of the four Agrostis species was exposed to three replications of each Prthium species. The plates were incubated at room tomperature $\left(24^{\circ}\right.$ to $\left.30^{\circ} \mathrm{C}\right)$ under fluorescent lights arranged so that the light intensity at the agar gel surface was 100 foot candles.

Counts were mede of the number of seeds that germinated and of those that did not germinate after seven days of incubation. The per cent germination was determined for each replicate. An adjustment or correction factor to allow for nonviable seed was calculated by dividing the average per cent germination of the unexposed controls into the average per cent germination of the Prthium-exposed seed (Table 3 ). The average per cent seed germination of the unexposed controls were: A. alba, 41 per cent; A. canina, 40 per cent; 4. palustris, 74 per cent; and $A$. tenuis, 73 per cent. In all cases the fungus covered the surface of the agar before germination of the seeds was observed. In some tests where a highly pathogenic Prthium specles was involved, a fer seeds Ifing adjacent to the inoculum germinated, while seeds at some distance from the inoculum which were covered with mycelium did not germinate.

The data indicating the relative pathogenlcity of species 
Table 3. Relative pathogenicity of Pythium species to germinating seeds of Agrostig species.

\section{Depression of seed}

Prthlum species A. alba A. canina A. palustris A. tenuis

P. aphan1dermatum * $7.9 \quad 7.9 \quad 5.5 \quad 9.9$

P. arrhenomanes

0.0

1.2

2.3

0.0

R. artotrogus

93.0

93.5

92.0

104.0

P. debaryanum

96.0

87.9

61.0

54.0

P. graminicolum

0.0

$2 \cdot 3$

$4 \cdot 5$

18.0

P. 1rregulare (H)**

84.7

58.8

46.0

66.9

P. 1rregulare

$(0) * 70.7$

52.5

27.6

34.4

P. Eplendens

40.4

35.8

30.4

47.7

‥ ult1mum

58.6

39.4

59.0

80.0

* Per cent germination of Agrostis seed when compared to viable seed not exposed to the particular Prthlum species.

* (H) and (O) refer to the Haralian 1solate and the Ohio isolate, respectively. 
of Pythium to germination of the viable seeds of the four Agrostis apectes are presented in Table 3.

\section{B. Pyth1um infury to 1grost1s seedlings.}

In order to determine the degree of pathogenicity of the various Pvthium species to seedlings of Agrostis species, seeds surface sterilized in sodium hypochlorite were aseptically placed on 1.5 per cent agar-water gel in petrl plates. The petri plates were spawned nine days later with the var1ous Byth1um specles by placing three $5 \mathrm{~mm}$. agar disks bearling acellum of the desired Iungus equidistantly on the agar gel surface. Bach of the four Agrostis species was exposed to three replicates of each Pyth1um spec1es. Petr1 plates containing seedlings, but without the fungus, served as controls. All plates were incubated at $27^{\circ} \mathrm{C}$ under fluorescent lights arranged so that the light intensity at the agar gel surface was 200 foot candles. Results were recorded twenty-one days after 1ntroducing the fungus 1nto the petri plates. In all cases, the Pyth1um species grew to cover the ent1re agar surface.

Injury to the seedlings was of two types: 1) leaf blighting, and 2) distortion and reduction in both length and number of root halrs. Moderate to severe blighting of the follage of all four grasses was caused by $\underline{P}$. arrhenomanes,

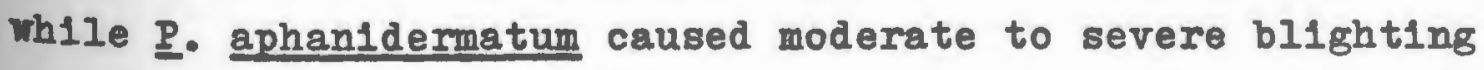
on A. alba, A. palustris and A. tenuis. None of the other Whium species caused blighting of the Agrostis seedlings. No discolored or necrotic areas were observed in the roots of 
any of the grasses. The Agrostis roots in the control plates produced an abundance of root halrs, nearly all of which were parallel to one another. Several of the Prthium species caused the root halrs to be reduced in number, as well as being bent and distorted. Table 4 shows the relative degree of injury to the Agrostis roots caused by the various Pythium species. 
Table 4. Relative pathogenieity of Prthium species to roots of Agrostis species.

\begin{tabular}{|c|c|c|c|c|}
\hline \multirow{2}{*}{$\frac{\text { Pvthium species }}{\text { P. aphanidermatum }}$} & \multicolumn{4}{|c|}{$\begin{array}{l}\text { Degree of infury to Agrostis } \\
\text { seeding roots }\end{array}$} \\
\hline & Mediuml/ & slight & Severe & Severe \\
\hline P. arrhenomanes & Medium & Severe & Severe & Severe \\
\hline P. artotrogus & None & None & None & None \\
\hline P. debaryanum & None & Slight & slight & Medium \\
\hline P. graminicolum & slight & slight & Slight & None \\
\hline P. Irregulare $(H)^{2} /$ & None & None & Slight & None \\
\hline P. Irregulare $(0)^{2}$ / & None & None & None & None \\
\hline P. solendens & None & Slight & slight & Slight \\
\hline P. ultimum & Medium & Medium & Medium & Medium \\
\hline
\end{tabular}

I/Estimated degree of distortion and reduction in both length and number of root hairs as compared to the controls. $2 /($ H) and (O) refer to the Hawailan and Ohio isolate, reapectively. 


\section{DISCUSSION}

Evidence has been accumulated from the literature and by experimentation to advance knowledge of the Marasmius fairy ring disease of turfgrasses and its control. Both chemical and blological control of the causal fungus have been of interest. After two years of trial of chemical measures and the better defining of their shortcomings, the field of antagonlstic fungl for blological control was explored. Soll inhabiting fungl were found that retard the growth of agaricaceous fung1 and of these Prthium artotrogus was selected for detalled study. Hence, the antagonistic relationship between Prthium species and Marasmius oreades and the mechanism of the antibiosis have been examined.

Present chemical control measures for fairy ring do not appear to be effective or practical. The one exception to this statement may be fumigation of the soil with methyl bromide. However, this drastic treatment kills the grass and the area cannot be reseeded or resodded for seven to fourteen dejs (12).

In this study much difficulty was experienced in forcing the solution injection probe into the soll in the dead grass zone of the fairy ring. In adjacent healthy turf no such difficulty was encountered. Molliard (27) and others have show that the soll beneath the dead grass zone is extremely dry and permeated by the fungus mycellum. Bayliss-Elliott (4) stated that this dry soll was extremely difficult to wet. The dryness of the so11 in the dead zone and its resistance 
to retting were, no doubt, the reason for the difficulty acountered in pushing the probe down to a depth of twelve inches.

It is these same soll conditions which make chemical control of falfy ring ineffective. It was thought that the addition of a nonionic wetting agent to the treatments might overcome the resistance of the soll to retting. The results have shown, however, that the addition of such a wetting agent to the fungicides does not completely solve the problem. Hence, other measures for ridding turfgrass sod of fairy ring fungl were sought.

Fergus et al. (15) reported that Pythium artotrogus completely inhibited the growth of Agaricus bisporus. Thus it was decided to determine if this, or other Pythlum species, could be used as a biological control agent for Marasmius falry ring.

There are many articles in the literature whlch suggest that varlous microorganisms have an antagonlstic effect on species of Pythium. For example, Connell (10) reported that out of 5,638 1solates of bacteria tested, 202 were antagonist1c to P. arrhenomanes. Thile investigating flve so1l types, Cooper and Chilton (11) tested over 8,000 1solates of actino-

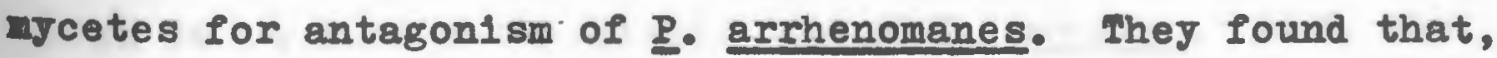
depending on the type of soil, 18.5 per cent to 31.5 per cent of the isolates were at least slightly antagonistlc. Butler (8) has reported that Rhizoctonia solan1 parasitizes some species of Prthium, but not others. Partial blological 
control of an unidentified Pythium species was obtained by Vright (39) when the seed of white mustard was dusted with spores of varlous Peniclilium and Prichoderma species.

However, after a thorough search of the literature only three reports which state that species of Pythium are antagonistic to other fungl have been found. Two of these were by Drechsler $(13,14)$ and concerned three Pythium species parasitic on other Pythium species. The third report was the previously mentioned article by Fergus et al. (15) in

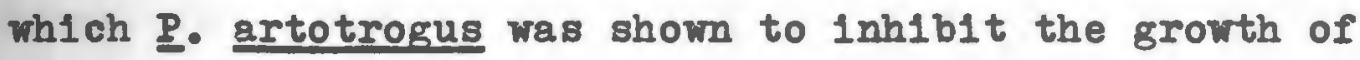
Agaricus bisporus.

Considering these inconclusive findings, the observations on the antagonism of $A$. b1sporus and $\underline{x}$ oreades by Pythlum species recorded herein are novel. Controlled experiments revealed that of nine Pythium 1solates tested, elght reduced by almost one half or more the mycelial growth of A. b1sporus. Species of Prthium were shown to be equally antagonistic to $M$. oreades, although the degree of antibiosis varled greatly among the Prthium species. Pythium artotrogus was shown to be less effective in reducing mycellal growth of M. oreades than that of $A$. bisporus. Pythium ultimum and the and the Hawalian isolate of $\underline{P}$. Irregulare, however, were shown to be more antagonistic toward $M$. oreades. Yet, the

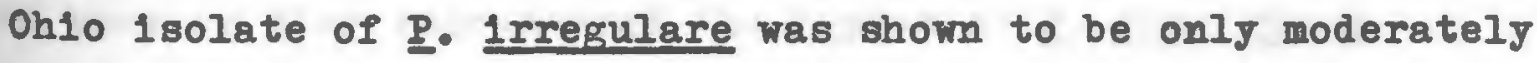
antagonistic to $\underline{\underline{M}}$. oreades.

While evaluating the pathogenicity of Pythium species on grasses, Sprague (35) noticed that various 1solates of 
P. debarjanum, $\underline{P}$. ultimum and $\underline{\underline{P}}$. 1rregulare differed markedly in their relative pathogenicity. These results seem to indicate that at least some species of Pythium exist as physiological or pathogenic races, which can be distinguished on the basis of their ability to cause disease in plants or to retard the growth of other fung1. This being the case, other 1solates of P. artotrogus should be tested to determine the degree of their antagonlsm toward $\underline{y}$ - oreades, and possibly to other fungi which cause the turfgrass fairy ring disease syndrome.

The older hyphal cells of 1 . bisporus were observed to have colorless, needle-shaped crystals lying on their exterlor walls. Heln (19) reported finding similar crystals, 1dentifled as calcium ozalate, on the hyphae of th1s fungus. These erystals were reported to vary from 1 to $20 \mathrm{u}$ in length, whlle the width varled from less than 1 a to $3 \mathrm{u}$. The older hyphal cells of $\underline{\underline{y}}$. oreades were also observed to have needleshaped crystals lying on the exterior of the hyphae. These crystals were generally wider, shorter, and with blunt ends in contrast with the pointed ends of those of A. b1sporus. Th1s appears to be the first report of the existence of such erystals on the hyphae of $\underline{\underline{M}}$. oreades.

The hyphal tips of $\underline{x}$ oreades did not all stop growing as soon as they encountered the hyphae of $\underline{\underline{P}}$ artotrogus.

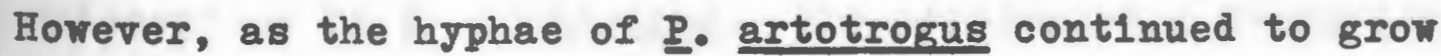
am1dst the mycelium ㅆ. oreades, more hyphal tips of the latter were inbibited. The two used culture filtrate agar 
experiments caused the hjphae of $\underline{M}$ oreades to develop at Ioduced growth rates. When the cultural filtrate of $\underline{P}$. artotrogus was applied directly to the hyphal tips of $\underline{M}$. oreades, twenty minutes were required before growth of the latter was completely inhibited. These experiments indicate that the toxic metabolite(s) of $\underline{B}$. artotrogus is relatively slow acting.

The experiments in which $\underline{\underline{M}}$. oreades and $\underline{P}$. artotrogus were grown on culture slides indicated that the antibiotic(s) of P. artotrogus does not diffuse in advance of the hyphae to any great extent. This may be due in part to the extremely high growth rate (as much as 17 u per minute) of this fungus on the substrates used in these studies. The toxic agent(s) must, however, be somewhat water soluble and diffuse through the agar, since growth of the hyphal tips of M. oreades was inhibited before their phjsical contact with the hyphae of P. artotrogus.

There were two striking differences between the antagonism to $\underline{M}$. oreades and to $\underline{A}$. bisporus by $\underline{\underline{P}}$. artotrogus. During the interaction between $\underline{M}$. oreades and $\underline{P}$. artotrogus the agar turned brown in the interhyphal zone and the hyphae of $\underline{x}$ oreades appeared to be lysed leaving a residue of arystalline material. Iysis did not occur and the agar in the interhyphal zone did not turn brown when $A$. b1sporus was

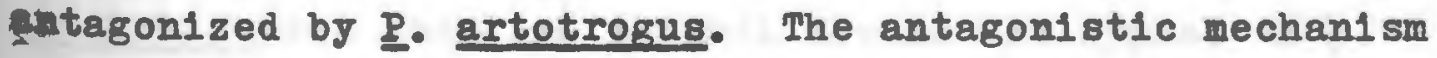
between P. artotrogus and each of the basidiomjcetes is therefore different, at least in the final stages of the interaction. 
The results of the used culture filtrate experiment in

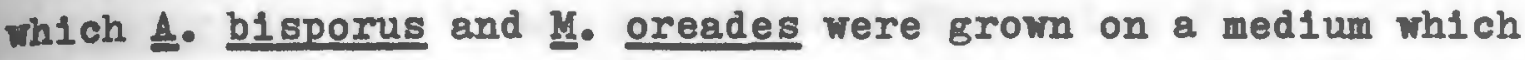
had previously been used as a substrate for $\underline{\text { P. artotrogus, }}$ indicated that $\underline{P}$. artotrogus was more antagonistic to $\underline{M}$. oreades than to $A$. bisporus. However, the data in Table 2 indicate that $\underline{P}$. artotrogus is more antagonistic to $A$. bisporus than to $\underline{M}$. oreades. The latter situation is more likely the correct one, since the toxic metabolite(s) produced by $\underline{P}$. artotrogus in the used culture f1ltrate experiment had been autoclaved.

The culture filtrate of P. artotrogus was shown to completely inhibit the growth of M. oreades within twenty minutes. Furthermore, the activity of the filtrate was not reduced when 1t was stored at $7^{\circ} \mathrm{C}$. The biological activity of the filtrate was lost, however, when dried under vacuum at $60^{\circ} \mathrm{C}$. It appears that the toxic agent(s) of the filtrate is thermolabile.

Drechsler (14) reported that P. oligandrum parasitized twelve species of Pythium including P. arrhenomanes, P. butlert (synonymous with P. aphanidermatum (26)), P. debaryanum, P. graminicolum, P. irregulare, P. splendens and P. ultimum. Of the species tested, P. artotrogus has been shown to parasitize all of these species, except $\underline{\underline{P}}$. graminicolum and $\underline{\underline{P}}$. arrhenomanes. Although not parasitic, the hyphae of $\underline{P}$. artotrogus was observed to coll around the hyphae of $\underline{P}$. arrhenomanes, Thy the hyphae of $\underline{P}$. artotrogus colled around the hyphae of $\underline{P}$. arrhenomanes, but falled to penetrate, 
camnot be explained at this time. One could argue that g. artotrogus might have paraitized the hyphae of $\underline{P}$. arrhenomanes if the culture slides had been incubated for more than forty-eight hours. This is a possibility, but it does not seem likely since spores of such slower growing fung1 have been shown to germinate, grow extensively and produce appressoria on the surface of a leaf all wthin thirty-s1x hours (1).

Drechsler's $(13,14)$ description, drawings and photo-

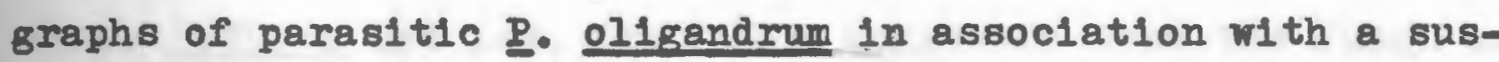
- eptible Pythium species are very similar to those presented in this paper for P. artotrogus.

Butler (8) reported that Rhizoctonla solant parasitized several Prthium apecies. The hyphae of $\mathrm{R}$. solani were observed to coll around the Prthium hyphae prior to penetration. He reported that colling and penetration was the result of a thigmotropic response. Penetration of the hyphae was stated to be the result of physical pressure and not enzymatic decomposition of the wall material. Concerning the initiation of parasit1sm, Butler (8) stated: ".....hyphal co1ls and Infection hyphae are formed by ․․ solani as a result of chemical stimuli produced on the surface of the hyphae of the host and parasite respectively. These substances seem to act in a complementary manner to determine the mode of infection. It could be further postulated that the relative amounts of each of the substances produced by the host and parasite determine the intensity of penetration and formation of parasitic coils." 
In h1s paper, Drechsler (14) reviewed a number of articles in which $\underline{\underline{P}}$. artotrogus was reported to be closely associated with Phytophthora and other Pythium spectes. De Bary as early as 1881 was reported to have noticed this

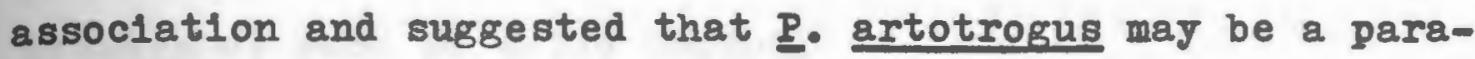
site on congenertc forms. Many of these earller workers based their identification of $\underline{\underline{P}}$. artotrogus on the size and shape of the spiny oogonla. Since he found three spectes of Pythium, each producing spiny oogonla, to be parasitic on other Pythium species, Drechsler suggested that the fungi may have been 1mproperly 1dentified. The present investigation has shown that $P$. artotrogus 1s, as was suggested by de Bary, a parasite of Pythium species.

The effect of temperature on growth of $\underline{\underline{P}}$. artotrogus has been reported by M1ddleton (26) and Fergus et al. (15). These workers used corn meal agar as a substrate, while a 2 per cent glucose agar medium was used in the present investigation. Pythium artotrogus grew at all temperatures at which $\underline{M}$. oreades grew, as well as at higher temperatures. The optimum temperature $\left(25^{\circ} \mathrm{C}\right.$ to $\left.27^{\circ} \mathrm{C}\right)$ for both organisms was nearly identical. The growth rate of $\mathrm{g}$. artotrogus was shown to be greater than that of M. oreades at all temperatures, and was greater by a factor of almost ten at the optimum temperature. Insofar as temperature requirements, P. artotrogus could qualify as a successful blological control agent for $\underline{\underline{\mu}}$. oreades.

The hydrogen-1 on requirement was quite simllar for both 
P. artotrogus and $\underline{M}$. oreades. The optimum $\mathrm{pH}$ for growth of both organisms was about 5.5. The range at which growth of P. artotrogus occurred was greater than that of $\underline{y}$. oreades. The growth rate of $\underline{\underline{P}}$. artotrogus was greater than that of $\underline{\underline{M}}$. oreades at each $\mathrm{pH}$ value tested.

The isolate of $M$. oreades used in this invegtigation was obtained from an athletic field in which the pH of the soll ranged from 4.7 to 5.0. The mycellum of this fungus was found in abundance in the soll, as well as in the layer of thatch composed primarliy of living and dead plant tissues. The $\mathrm{pH}$ of the layer of thatch varled from 5.0 to 6.0 . The relatively high $\mathrm{pH}$ of the thatch layer was probebly due to previous limestone applications on the follage. Hence, present data indicate that hjarogen-ion concentration would rarely limit the effectiveness of $\underline{P}$. artotrogus as a blological control agent for $\underline{\underline{M}}$. oreades. Similarly, Agaricus b1sporus (campestris) has been shown (16) to tolerate a pH range from about 4.0 to 8.0 wth an optimum of 6.0 . Fergus et al. (15) reported that the growth of $A$. blsporus is com-

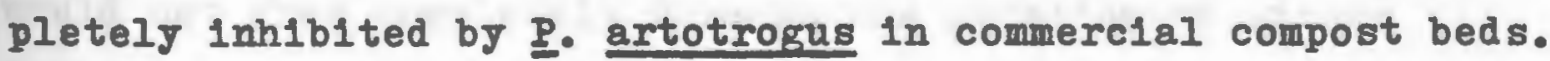
Sprague (34) observed that $\underline{P}$. arrhenomanes, $\underline{P}$. debaryanum,

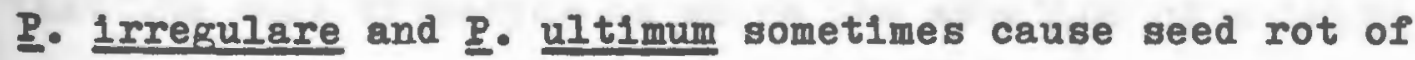
species of Gramineae. The results of the pathogenicity tests conducted in the present study show that $\underline{P}$. aphanidermatum, P. graminicolum and P. splendens can be added to this list. Pythium artotrogus, however, was shown to cause a negligible amount of seed rot of the four Agrostis species used in this study. 
The results of the pathogenicity tests of Pythium opecies to seedlings of Agrostis apecies did not agree completely with the data in the literature. Prthium aphanidermatum has been reported to cause a blighting of the foliage of A. palustris $(28,29)$, which agrees with the data presented in this study. Moore et al. (30) found that P. ultimum caused a blight of Highland Colonial bentgrass, but in the present study it did not blight the follage of Astoria colonial bentgrass.

Pythium artotrogus caused no significant infury to any of the Agrostis seedlings tested. Unlike other species of Prthium which were antagonlatic to $\underline{M}$. oreades, $\underline{\text { P. artotrogus }}$ could be used as a blological control agent without causing Injury to Agrostis species.

Although Fergus et al. (15) reported that $\underline{P}$. artotrogus completely inhibited the growth of $A$. bisporus in manure compost, 1ts growth was retarded about 70 per cent and that of ㅆ. oreades about 60 per cent under the laboratory conditions used in this study. Studies showed that P. artotrogus would not grow completely through the mycelium of either A. blsporus or M. oreades. Bajliss-Illiott $(4,5)$ pointed out that the only direction in which the mycelium of a fairy ring grows is in an outward direction. Thus, for P. artotrogus to be a successful blological control agent, the fungus will have to be applied to the turf in advance of the fairy ring symptoms.

Temperature and hydrogen-1on tolerance studies have 
shown that the growth rate of $\underline{P}$. artotrogus was greater than M. oreades at all temperatures and hydrogen-1on concentrations tested. This also supports the possible use of $\underline{P}$. artotrogus as a biological inhibitor of $\underline{M}$. oreades. Although other Pythium species were shown to be more

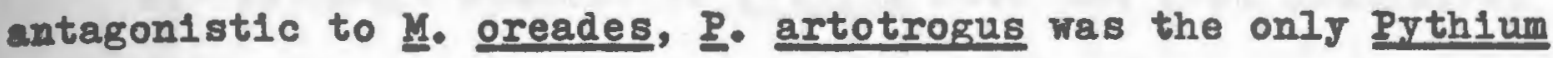
apecies tested that was not pathogenic to four bentgrass species, an important consideration when selecting a biological control agent.

These data indicate that $\underline{\underline{P}}$. artotrogus has the potential for use as a blological control agent for falry ring disease caused by $M$ oreades. 


\section{CONCLUSIONS}

1. Direct application of chemicals for the control of the Marasmius fairy ring disease of turfgrass is not practical at present.

2. Nlthough species of Pythium have not been considered as being antagonistic to other fung1, it has been shown that many species of Pythlum are antagonistic to 1 . b1sporus and to $\underline{y}$. oreades. Pythium artotrogus was more antagonistic to A. b1sporus than any of the other Pythium species tested. Prthium ultimum and the Hawalian 1solate of $\underline{\underline{P}}$. irregulare displayed greater antagonism towards $\underline{\underline{M}}$. oreades.

3. Prthium artotrogus evidently produces a toxic metabolite(s) which inhibits the growth of $\underline{M}$. oreades. The toxic agent(s) is at least partially water soluble and will diffuse through agar, but it is thermolabile.

4. Pythium artotrogus is not endoparasitic on the hyphae of A. b1sporus or $\underline{M}$. oreades.

5. Pythium artotrogus was shown to be endoparasitic in the hyphae of $\underline{\underline{P}}$. aphanidermatum, $\underline{\underline{P}}$. debaryanum, $\underline{\underline{P}}$. irregulare, P. splendens and P. ultimum.

6 . The hyphae of $\underline{\underline{P}}$. artotrogus were observed to coll around the hyphae of the host prior to penetration. The 1nfection hyphae of $\underline{\underline{P}}$. artotrogus grew lengthwise within the host's hyphae causing degeneration of the protoplasm.

7. Temperature and hydrogen-1on tolerances of $\underline{\underline{P}}$. artotrogus and $\underline{M}$. oreades are similar.

8. Pythium artotrogus was shown to cause no injury to 
70.

seeds or seedlings of four species of Agrostis. 
XIII. SUMMARY

Pairy ring of turfgrasses, caused by Marasmius oreades and other fung1, have long been a problem to those interested in maintaining fine turf. Chemical control of Marasmius fairy ring has been shown to be ineffective at the present time, thus other types of control measures were sought.

This investigation has shown that many Pythium species inhibit the growth of $A$. bisporus and $\underline{M}$. oreades. Pythium artotrogus was more antagonistic to $A$. bisporus than any of the other Prthium species tested. Pythium ultimum and an 1solate of $P$. irregulare were more antagonistic to $\mathrm{M}$. oreades than was $\underline{P}$. artotrogus. Thus it appears that Pythium species may play an important role in the ecology of soll inhabiting Iungi.

Pythium artotrogus was shown to inhibit mycelial growth of $\underline{y}$. oreades by the production of a toxic metabolite(s) which diffuses through an agar medium. When a culture filtrate of $P$. artotrogus was applied directly to the hyphae of y. oreades, growth of the latter was inhibited completely within twenty minutes. The activity of the filtrate was not reduced when stored at $7^{\circ} \mathrm{C}$, but proved to be thermolabile.

Pythium artotrogus was not endoparasitic in the hyphae of $A$. bisporus or $\underline{M}$ oreades. It did parasitize the hyphee of P. aphanidermatum, P. debartanum, P. 1rregulare, P. Splendens and P. ultimum. The hyphae of $\underline{\text { P. artotrogus colled }}$ around the hyphae of a susceptible host. The parasite formed an appressorlum on the surface of the host hypha. Following 
penetration, the infection hypha grew lengthwise within the hypha of the host, degenerating the protoplasm as it adranced. 1lthough not parasitic, the hyphae of P. artotrogus coiled around the hyphae of $\underline{P}$. arrhenomanes. Pythium artotrogus did not form colls and was not parasitic on 1ts own or on P. graminicolum hyphae.

Studies on the effect of temperature on linear growth of

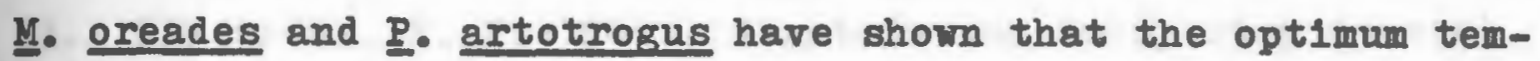
perature for both organisms to be near $27^{\circ} \mathrm{C}$. The minimum temperature at which growth occurred for both fungi was about $5^{\circ} \mathrm{C}$. The maximum temperature at which growth of $y_{0}$ oreades occurred was above $30^{\circ} \mathrm{C}$, while the maximum temperature for growth of P. artotrogus was between $34^{\circ}$ and $40^{\circ} \mathrm{C}$. At the various temperatures tested $\underline{\underline{P}}$. artotrogus had a growth rate of two to ten times greater than that of $\mathrm{M}$. oreades.

Although many species of Pythium were shown to be strongly antagonistic to $A$. bisporus and to $M$. oreades, only P. artotrogus was shown, in laboratory tests, to be nonpathogenic to four Agrostis species. Thus it appears that $\underline{P}$. artotrogus has the potential to be used as a biological control agent for M. oreades, the causal organism of Marasmius fairy ring. 


\section{IITERATURE CITED}

1. Adams, P. B., T. Sproston, H. Tietz, and R. T. Major. 1962. Studies on the disease resistance of Ginkgo b1loba. Phytopathology 52:233-236.

2. Albrecht, W. A., V. I. Sheldon, and W. G. Blue. 1951.

"Fa1ry ring" mushrooms make protein-rich grass.

Bull. Torrey Bot. Club 78:83-88.

3. Alexander, P. M. 1964. Nematode and falry ring control

on I1fgreen bermuda. Golf Course Reptr.32(5):12-14.

4. Bayliss-Elliott, Jessie S. 1911. Observations on

Marasmius oreades and Clitocrbe gigantes as parasitic fungl causing "fairy rings." J. Econ. Biol. $6: 111-132$.

5. Bayliss-Ell1ott, Jessie S. 1926. Concerning "fairy rings" in pestures. Ann. Appl. B101. 13:277-288.

6. Berkeley, M. J. 1846. Observations, botanical and physlological, on the potato murrain. J. Roy. Hort. Soc. 1:9-34.

7. Buller, A. H. R. 1958. Researches on Fung1. Vol. II. Hafner Publ. Co. New York.

8. Butler, E. E. 1957. Rh1zoctonia solan1 as a parasite of fung1. Mycologia 49:354-373.

9. Clinton, G. P. 1920. New or unusual plant injurles and diseases found in Connectlcut, 1916-1919. Connectlcut Agr. Expt. Sta. (New Haven) Bull. 222: 397-482. 
10. Connell, T. D. 1952. A survey of bacteria antagonist1c to Pythium arrhenomanes in Loulstana sugar cane so1ls. Phytopathology 42:464. (Abstr.)

11. Cooper, W. E., and J. P. Chilton. 1950. Studies on antiblotic soll organisms. I. Actinomycetes antiblotic to Pythium arrhenomanes in sugar cane solls of Loulsiana. Phytopathology 40:544-552.

12. Couch, H. B. 1962. Diseases of Turfgrasses. Reinhold Publ. Corp. New York.

13. Drechsler, C. 1943a. Antagonism and parasitism among some Oomycetes associated w1th root rot. J. Wash. (D.C.) Acad. Sc1. 33:21-28.

14. Drechsler, C. 1943b. Two species of Pythium occurring In southern states. Phytopathology 33:261-299. 15. Fergus, C. I., J. W. Sinden, I. C. Schisler, and Ed1th M. Sigel. 1963. Possible detrimental effect of Pythium artotrogus on the cultivated mushroom. Phytopathology 53:1360-1362.

16. Frear, D., J. F. Styer, and D. E. Haley. 1928. A study of the effect of H-1on concentration on the growth of Agaricus campestris. Plant Physiol. 3:91-94.

17. Gould, C. J. 1964. Turfgrass disease problems in North America. Golf Course Reptr. 32(5):36-54.

18. Hartley, C. 1921. Damp1ng-off in forest nurseries. U. S. Dept. Agr. Bull. $934: 1-99$.

19. Hein, I. 1930. Studies on the mycelium of Psalliota campestr18. Am. J. Botany 17:197-211. 
20. Hitchcock, A. S. 1951. Manual of the Grasses of the Unlted States. U. S. Dept. Agr., Misc. Publ. No. 200.

21. Howard, F. I., J. B. Rowell, and H. I. Ke1l. 1951.

Fungus diseases of turfgrasses. Rhode Island Agr. Expt. Sta. Bull. 308.

22. Lawes, J. B., J. H. G1lbert, and R. Warington, 1883.

Contribution to the chemistry of "fairy rings." J. Ohem. Soc. (Iondon) 43:208-223.

23. Iebeau, J. B., and E. J. Hawn. 1963. Formation of hydrogen cyanide by the mycelial stage of a falry ring fungus. Phytopathology 53:1395-1396.

24. Iindeberg, G. 1944. Über die physiologie ligninabbauender bodenhymenomyzeten studien an schwedischen marasmius-arten. Symbolae Botanicae Opsalienses $8(2): 1-183$

25. Mathews, V. D. 1931. Studies on the genus Prthium. Univ. of North Carolina Press, Chapel Hill. 26. Middleton, J. T. 1943. The taxonomy, host range, and geographic distribution of the genus Pythium. Mem. Torrey Bot. Club 20:1-171.

27. Molliard, M. M. 1910. De l'action du Marasmius oreades Pr. sur la vegetation. Bull. Soc. Bot. France $57: 62-69$.

28. Monte1th, J. 1933. A Pythium disease on turf. Phytopathology 23:23-24. (Abstr.) 
29. Monte1th, J., and A. S. Dahl. 1932. Turf diseases and

their control. J. S. Golf Asøn., Green Sect.,

Bull. 12(4):85-187.

30. Moore, I. D., H. B. Oouch, and J. R. Bloom. 1963.

-Influence of environment on diseases of turfgrasses. III. Effect of nutrition, pH, soll temperature, alr temperature, and so1l mo1sture on Pythium blight of H1ghland bentgrass. Phytopathology 53:53-57. 31. Shantz, H. I., and R. I. Plemelgel. 1917. Fungus falry rings in eastern Oolorado and their effects on vegetation. J. Agr. Research 11:191-246. 32. Smith, Virgin1a M. 1949. On the mechanism of enzyme action. LXXVI. Dehydrogenation studies on Merulius lacrymans and Marasmius chordal1s, and the mechanlsm of oxallc acid formation. Archiv. Biochem. 22: 275-287.

33. Sulth, พ. G. 1884. Diseases of Field and Garden Crops. MacMillan and Co., London.

34. Sprague, R. 1943. Root rots of Gramineae in the Northern Great Plains, 1940-43. Plant Disease Reptr. $27: 248-250$.

35. Sprague, R. 1944. Root rots of cereals and grasses in North Dakota. North Dakota Agr. Expt. Sta. Bull. 332.

36. Warcup, J. H. 1951. Studies on the growth of basidiomycetes in soll. Ann. Bot. ns 15:305-318. 
37. Wilkins, W. H., and Sheila H. M. Patrick. 1940. The ecology of the larger fung1. IV. The seasonal frequency of grassland fungl with special reference to the influence of environmental factors. Ann. Appl. B101. 27:17-34.

38. Wolpert, F. S. 1924. Studies in the physlology of fung1. XVII. The growth of certain wood-destrojing fungi in relation to the $\mathrm{H}-1$ ion concentration of the media. Ann. Missouri Bot. Gard. 11:43-97.

39. Wright, J. M. 1956. Blological control of a soil-borne Pythium infection by seed inoculation. Plant and So11 $8: 132-139$. 